\title{
Mahmud Sâmi Paşa el-Bârûdî’nin şiirinde sitem
}

\section{Serkut Mustafa DABBAGH ${ }^{1}$}

APA: Dabbagh, S. M. (2019). Mahmud Sâmi Paşa El-Bârûdî’nin şiirinde sitem. RumeliDE Dil ve Edebiyat Araştırmaları Dergisi, (14), 505-521. DOI: 10.29000/rumelide.541091

\section{$\ddot{O} \mathbf{z}$}

Bu makale, Mahmud Sami Paşa el- Bârûdî’nin şiirinde sitem konusunu ele almak amaciyla kaleme alınmıştr. Araştırmanın amacı genel olarak Arap şiirinde ve özellikle Bârûdînnin şiirlerinde sitem konularını incelemek ve şairin kardeşleri, akrabaları, halkı, devlet adamları ve sonsuzluk hakkında yaptığı sitemlerin sebeplerini öğrenmektir. Ayrıca bu araştırma Barudi’nin sitem amaçlı yazdığı en önemli şiirleri üzerinde durmaktadır. Bu konunun seçilme nedeni diğer araştırmacılar tarafından kapsamlı bir şekilde ele alınmamış olmasıdır. Bârûdî’nin divanını okunup incelendikten sonra sitem konusu ile ilgili olan bazı şiirlerinden ve kasidelerinden bazıları çıkarılmıştır. Bu araştırma önsöz, giriş, iki bölüm ve sonuçtan oluşmaktadır. Giriş bölümünde sitemin dil ve terminolojik açıdan tanımı bulunmaktadır. Ayrıca Arap şiirinin edebi dönemleri boyunca sitem konusunda bazı açıklamalar yer almaktadır. İlk bölümde: Mahmud Sâmi Paşa el-Bârûdî’nin doğumu ve yaşamı anlatılmaktadır. İkinci bölümde ise Barudi'nin şiirlerinde sitem konusu ayrıntılı bir şekilde ele alınmaktadır. Araştırmanın sonuç bölümde konunun en önemli sonuçları kaynakçalarıyla birlikte belirtilmiştir. Bu çalışmadaki araştırma metodu ise şairin sitem konusu ile ilgili olarak yazdığı şiirlerin şiirsel kanıtlar belirtilerek ele alındığı objektif bir yaklaşımdır.

Anahtar kelimeler: Sitem, Mahmud Sâmi Paşa el-Bârûdî, siyasi sitem, sosyal sitem, kader, Arap şiiri.

\section{Reproach in the poetry of Mahmoud Sami Pasha Baroudi}

\begin{abstract}
This research dealt with the purpose of repentance in the poetry of Mahmoud Sami Pasha Al-Baroudi, the aim of the research was to search for the topics of repentance in the poetry of the Arab in general and in the poetry of Baroudi in particular and to learn the reasons and causes of the reproach which the poet has made about his brothers, relatives, people, statesman. In addition, this research focuses on the most important poems of Baroudi in the purpose of repentance. The reason for choosing this topic is that it has not been comprehensively addressed by other researchers. After reading Baroudi's book poetry and reading it accurately, I was able to gather some of his poems and poems scattered about the subject of repentance. The research came in an introduction, a preface, two chapters and a conclusion. In the introduction, definition of repentance the terms of language and terminology. In addition to talking about the purpose of reproach in Arabic poetry through the literary ages. In the first chapter: A talk about the birth and life of Mahmoud Sami Pasha Baroud. As for the second chapter: Detailed topics were explained in the poetry of Barou. At the end of the research: The main results of the research are explained with references and sources of research. The research methodology; the approach I see as an occasion has been adopted in this study, is an objective
\end{abstract}

1 Dr. Öğr. Üyesi, Karamanoğlu Mehmetbey Üniversitesi, Edebiyat Fakültesi, Mütercim Tercümanlık Bölümü, (Karaman, Türkiye), smustafa@kmu.edu.tr, ORCID ID: 00oo-0002-8389-9749 [Makale kayıt tarihi: 22.01.2019-kabul tarihi: 20.02.2019; DOI: 10.29000/rumelide. 541091] 
approach, he talks with the poetry of the poet with a light on the topics of repentance and highlights the poetic evidence of each subject.

Key words: Research, Mahmoud Sami Pasha Baroud, political research, research repentance, forever, Arabic poetry.

\title{
العِتَّاب في شِعر مَحْمُود سَامِي باشَا الجَبَرُودي
}

\begin{abstract}
ملخص - - م م
تناول هذا البحث غرض العتاب في شعر محمود سامي باشا البارودي، ويهدف البحث إلى در اسة عن موضو عات العتاب التباب في شعر العربي

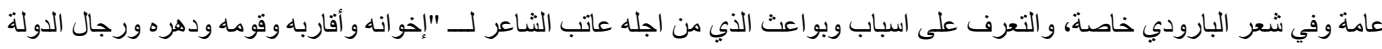

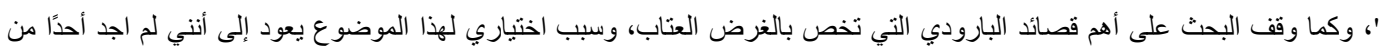

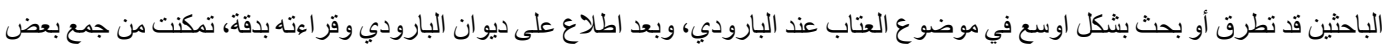

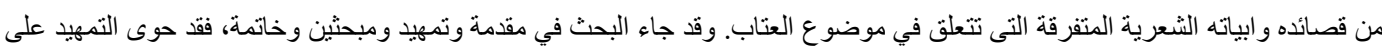

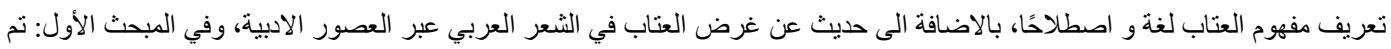

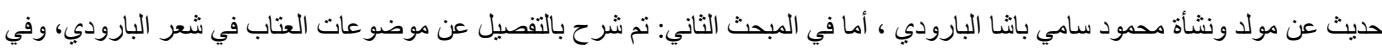

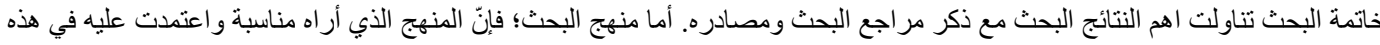

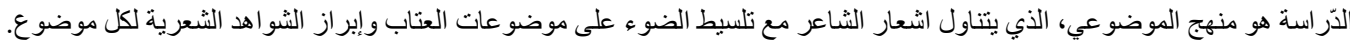

$$
\text { كلمات مفتاحية: العتاب، محمود سامي البارودي، العتاب السياسي، العتاب الإجتماعي، الدهر، الثعر العربي. }
$$

\section{التقديم}

الحمدلله والصلاة و السلام على حبيبه المصطفى و على آله و أصحابه الذين أخذو ا من نبيهه خير الأحكام و اقتدو ا به في السر اءو و الضر اءو وأتباعهم الذين اتبعو ا بإحسان وتابعيهم إلى يوم الدام الدين.

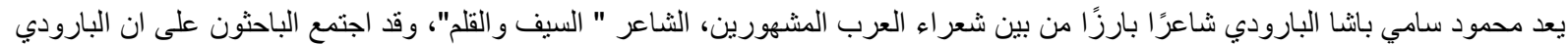

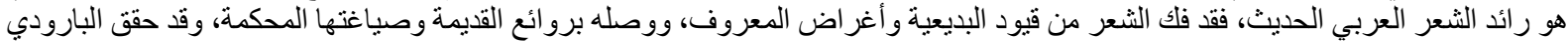

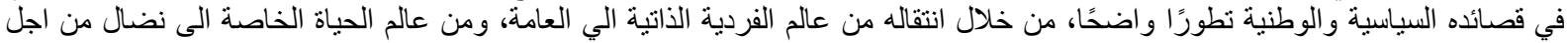

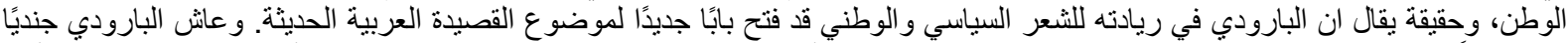

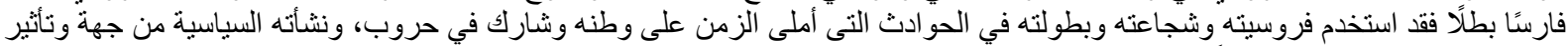

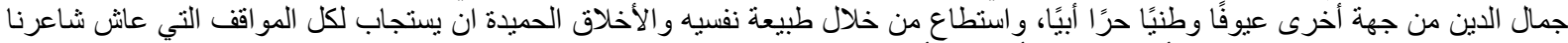

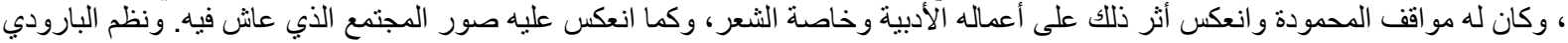

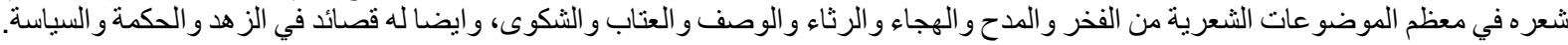

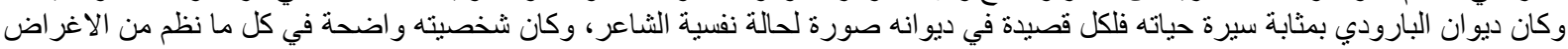

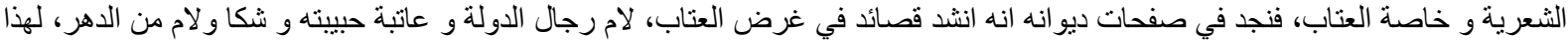

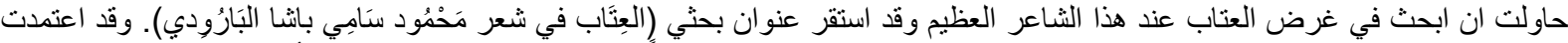

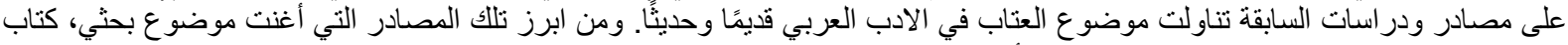

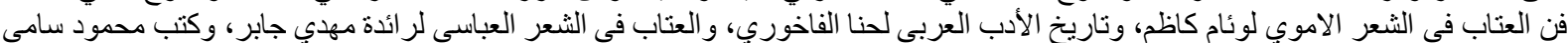

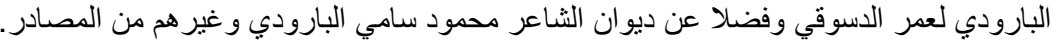

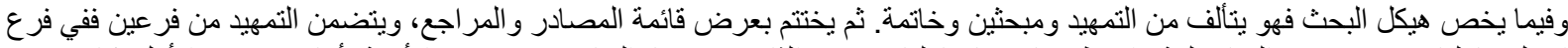

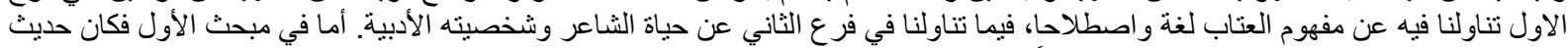

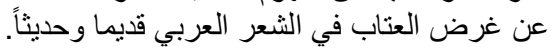

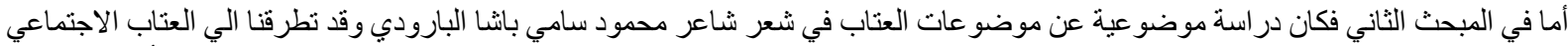

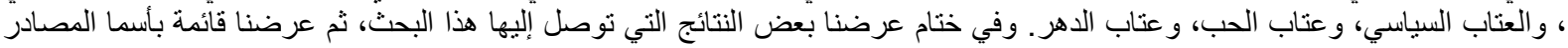
و والمراجع.

وفي الختام نسأل اله أجر ما قدمناه، فإن كنا موفقين في بحثنا هذا فهو من الله وله الفضل، إن كنا قد أخطأنا في تقديرنا فهو منا. 


\section{التمهيد \\ مَفْهُوم العِتَّبَ لُغَةُّو واصطلاحًا:}

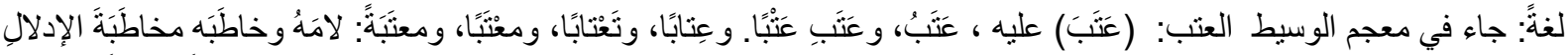

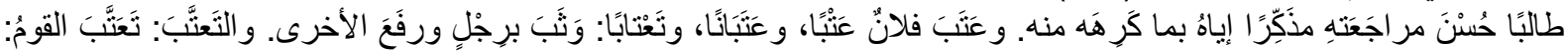

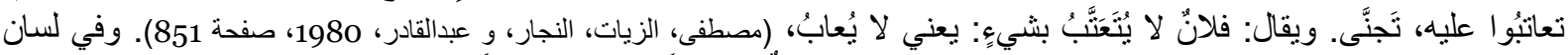

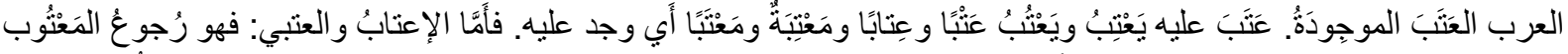

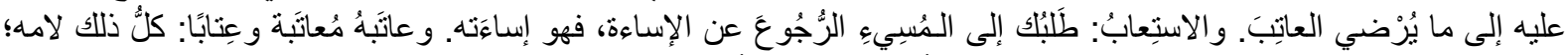

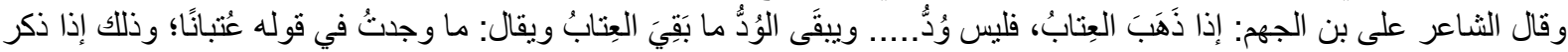

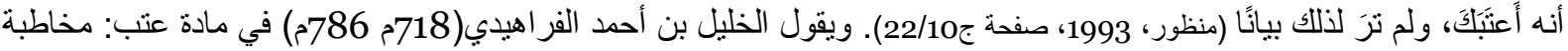

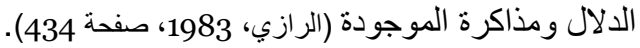

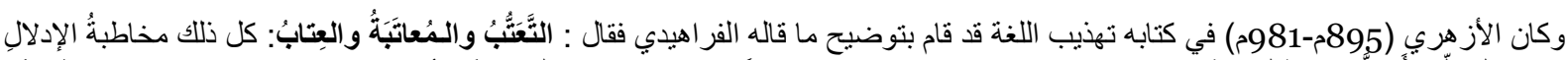

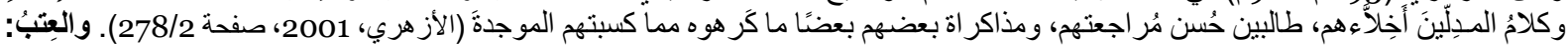

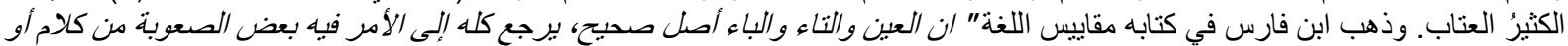

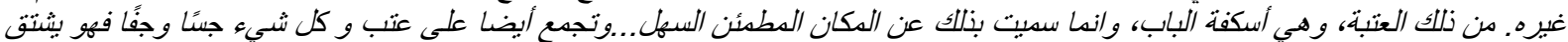

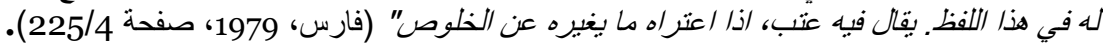

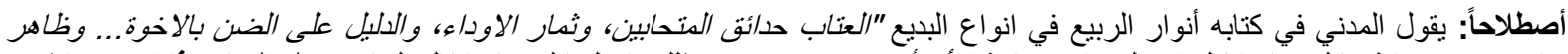

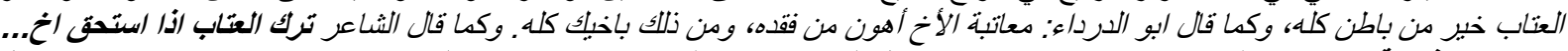

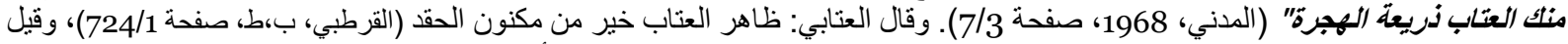

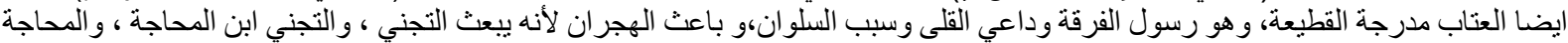

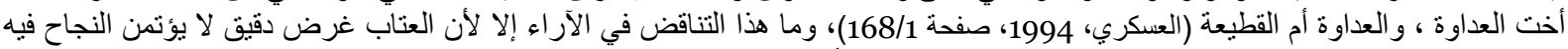

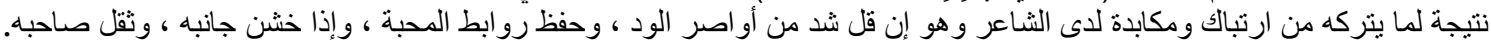

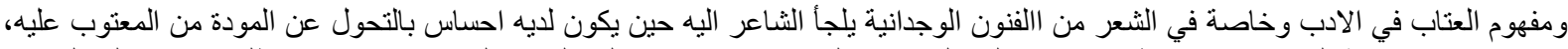

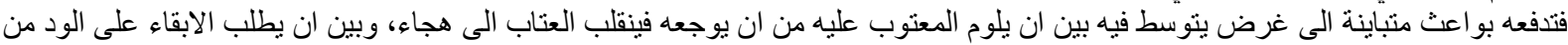

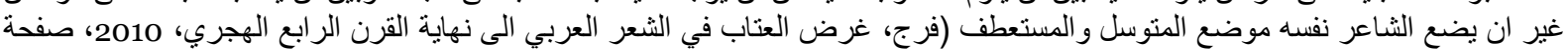

\section{غرض العتاب في الشعر العربي}

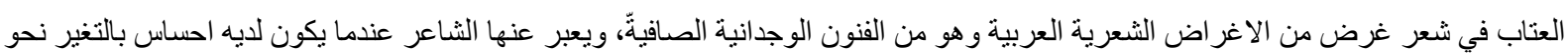

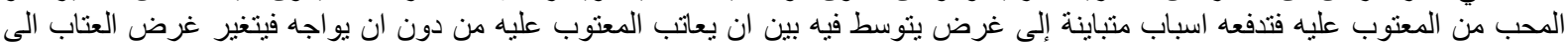

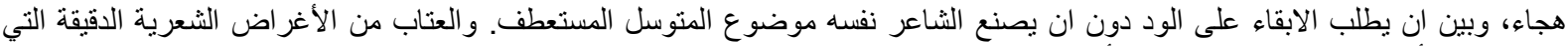

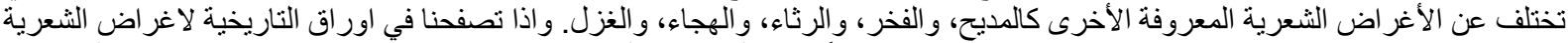

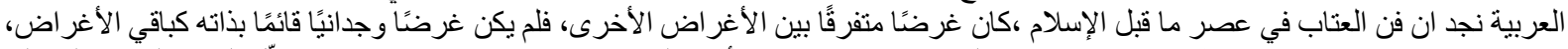

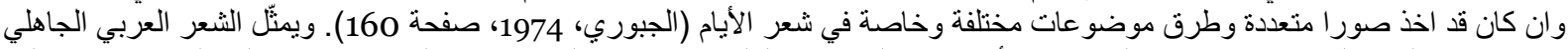

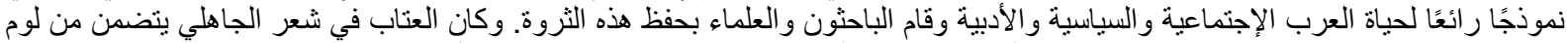

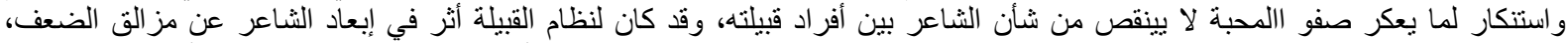

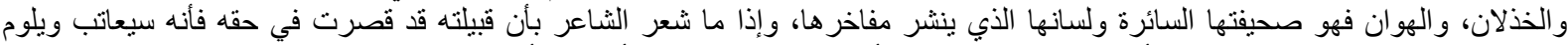

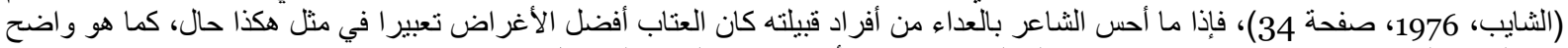

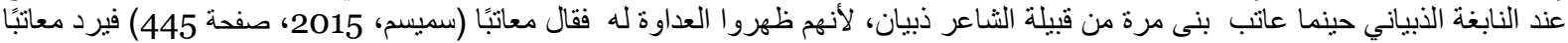
لهم في قصيدته تحت عنوان "ذات الصفا" فينشد ويقول:

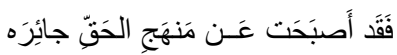

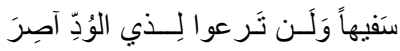

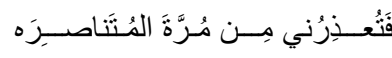

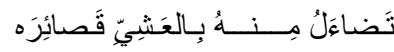

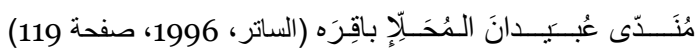

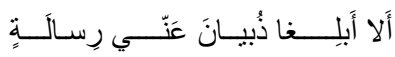

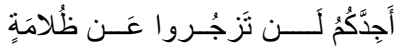

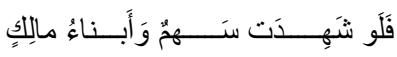

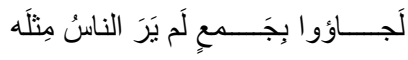

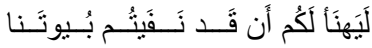

Kirklareli University, Faculty of Arts and Sciences, Department of Turkish Language and Literature, Kayalı Campus-Kirklareli/TURKEY e-mail: editor@rumelide.com 
ونجد الثـاعر زهير بن أبي سلمى يحث على عدم تكثر بالعتاب مثل الحقد والعدواة والاتهام بالجرم من الذنوبي، وسوف تبين للك ملامح الصداقة

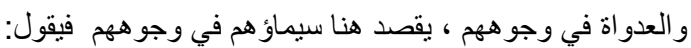

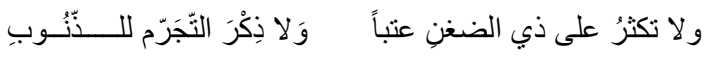

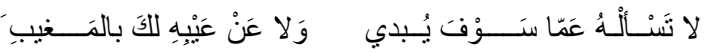

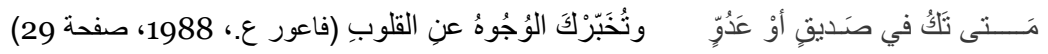

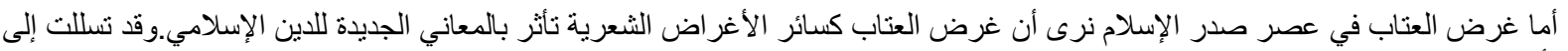

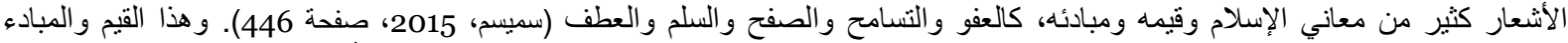

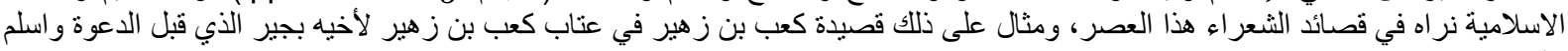

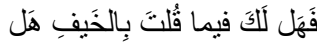

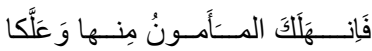

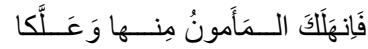

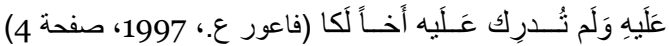

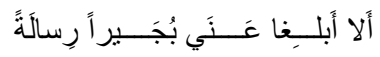

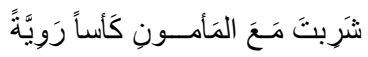

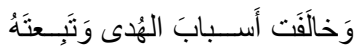

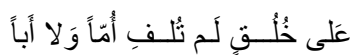

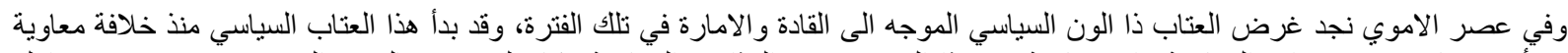

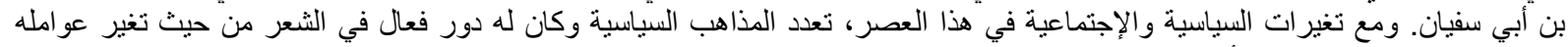

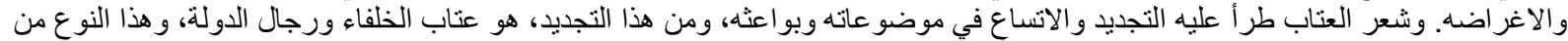

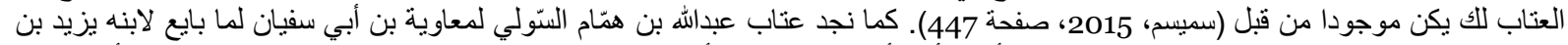

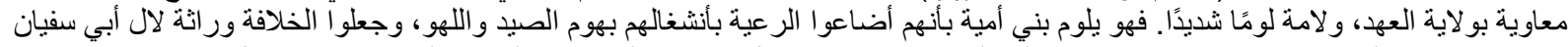

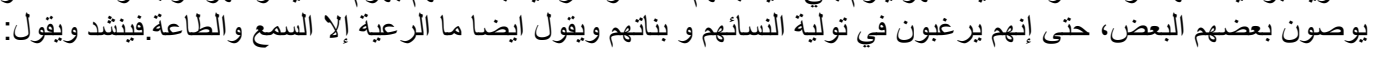

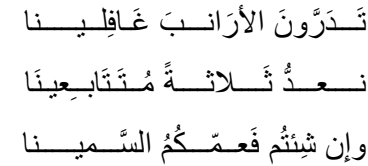

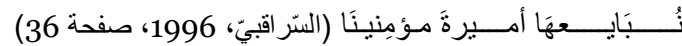

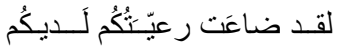

$$
\begin{aligned}
& \text { إذا ما ماتَّ كِسرَى قـامَ كِسْرَى }
\end{aligned}
$$

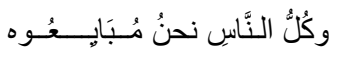

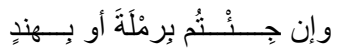

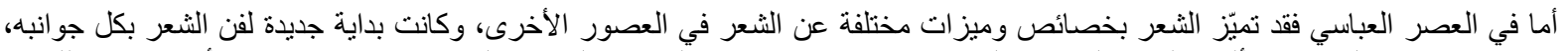

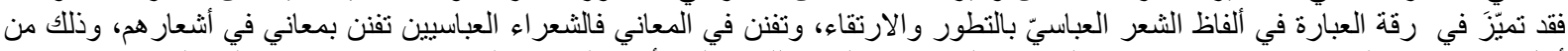

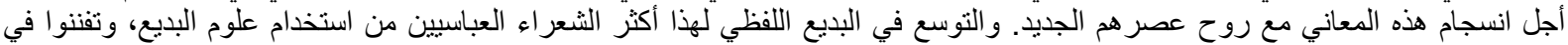

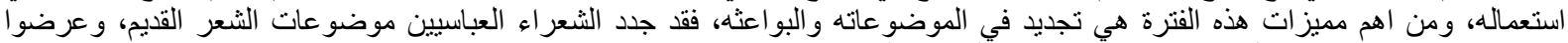

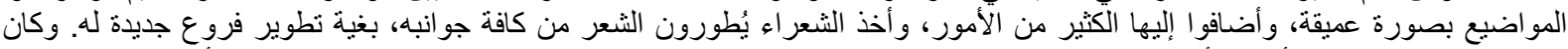

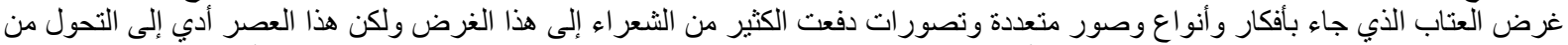

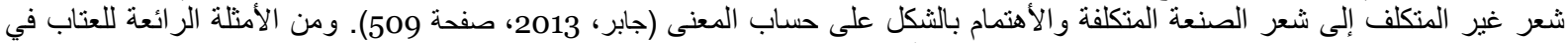

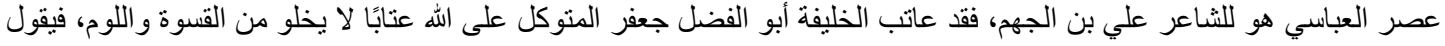

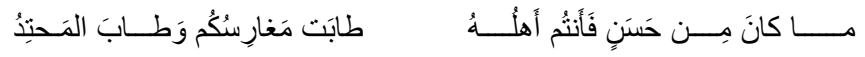

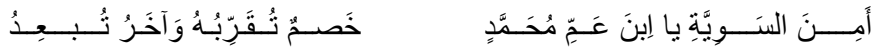

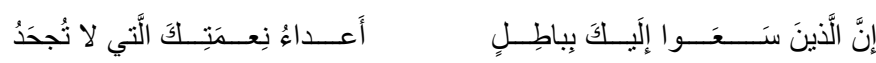

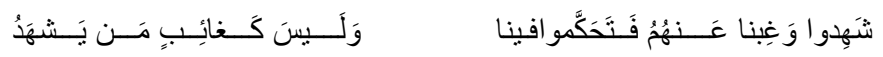

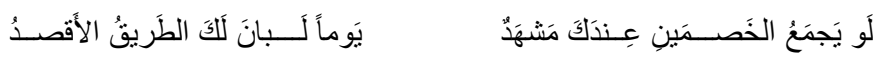

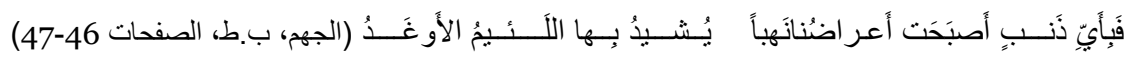

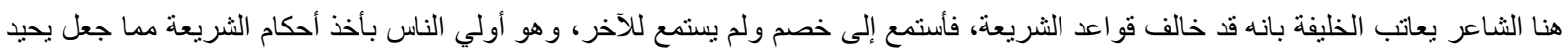

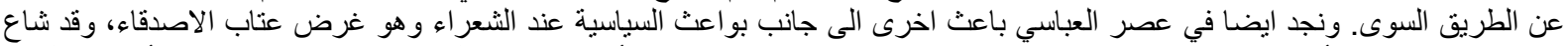

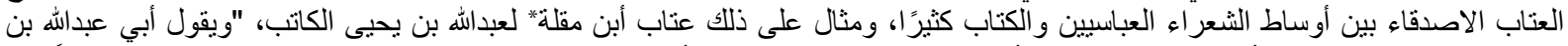

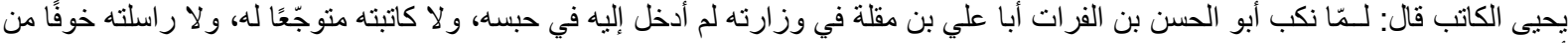

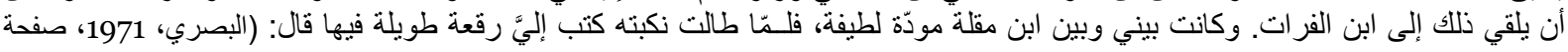

"ابن مقلة :هو محمد بن علي بن الحسين من أو ائل من كيفوا الخط العربي فسارت الأمثال بحسن خطه ووزر للمقتدر ، و القاهر توفي سنة 328هـ. 


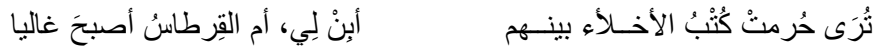

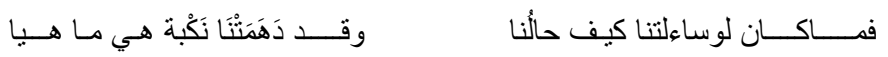

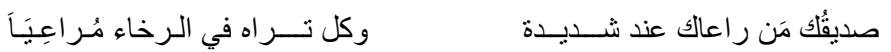

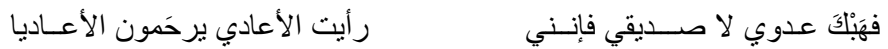

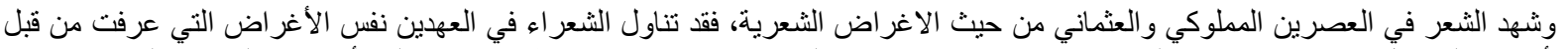

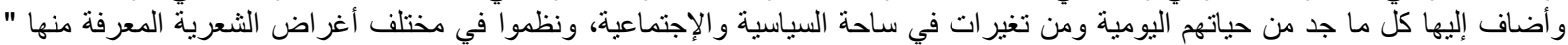

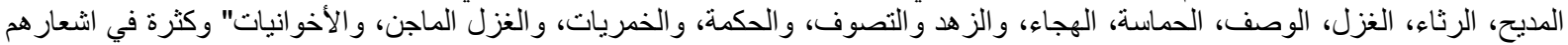

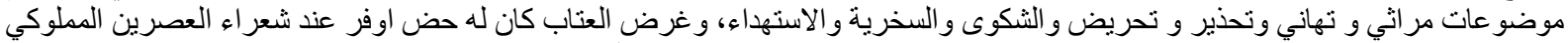

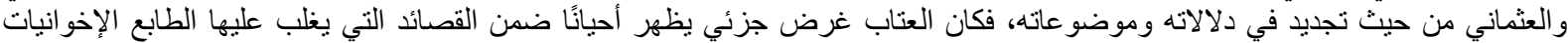

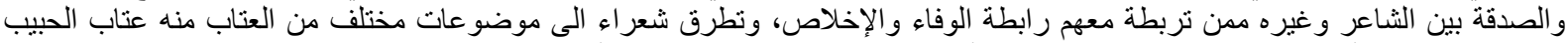
و الخليل و الدهر و الأحوال، ومن العتاب الصديق عتاب أبن حجة لصديقه المقر الاشرف الأميني (عمر م.، 2008) صاحب عاء ديوان الإنشاء بدمشق،

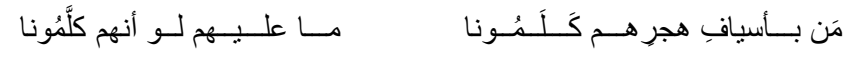

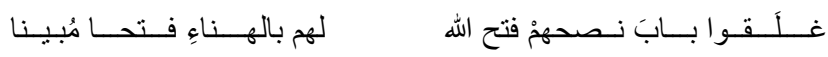

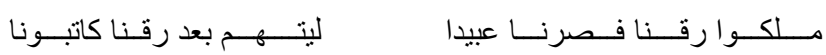

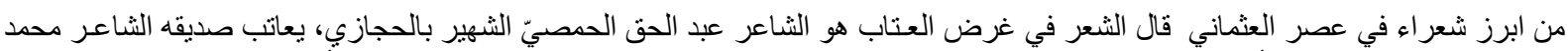

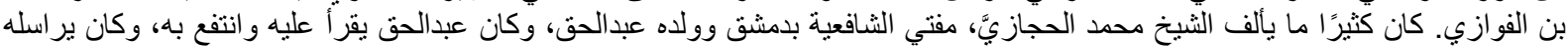

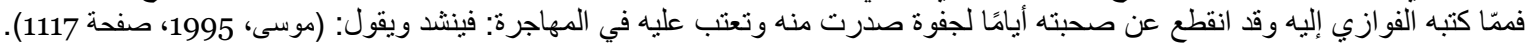

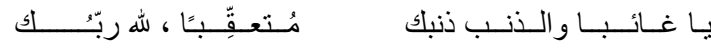

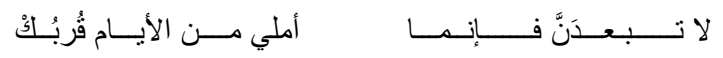

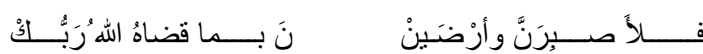

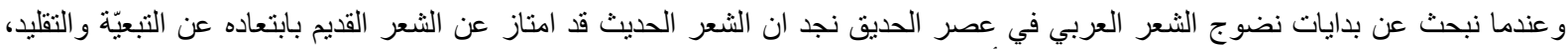

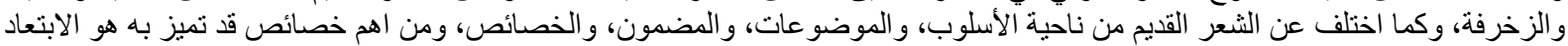

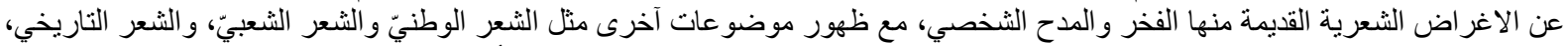

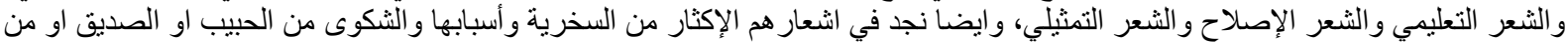

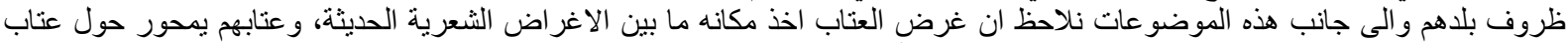

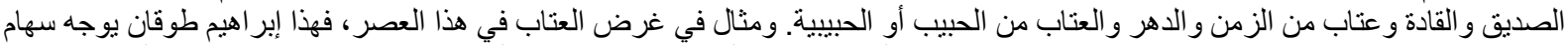

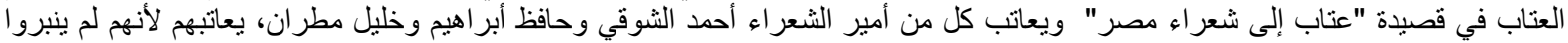
لللفاع عن قضية القدس وفلسطين فيقول:

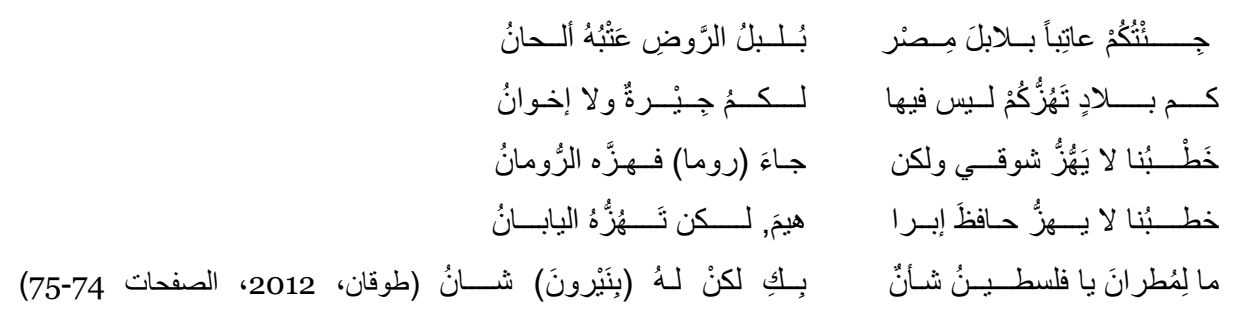

\section{البارودي؛ المولا والنشأة}

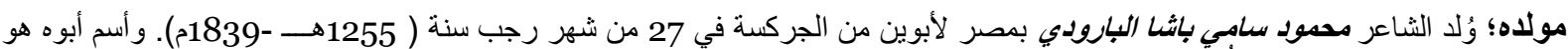

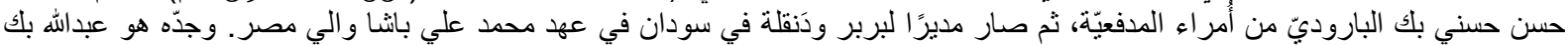

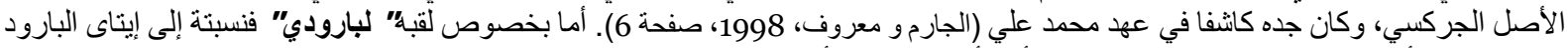

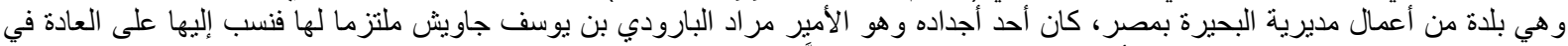

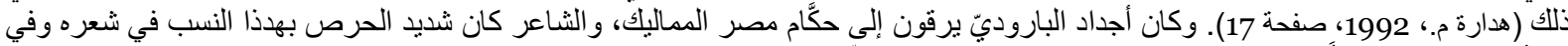

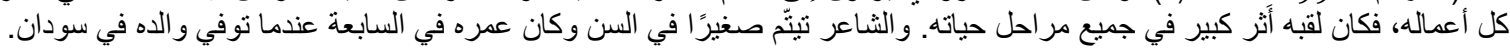
مر احل دراسته؛ و الثاعر تيتّم صغيرًا وحرم من العطف الأبويّ منذ نعومة أَظفاره، ومات أبوه في سودان و الثناعر في السابعة من عمره، " وكلفه

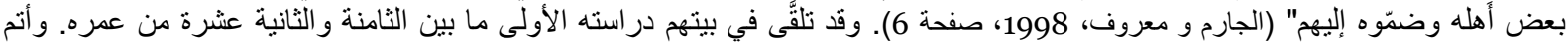

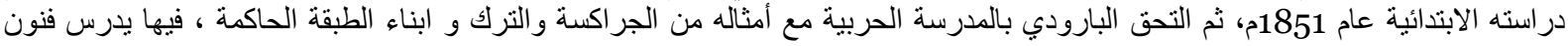


الحرب، وعلوم الدين و اللغة والرياضيات، وتخرج من من المدرسة الحربية سنة 1854م وهو في السادسة عشرة من عمره (الدسوقي، محمود سامي

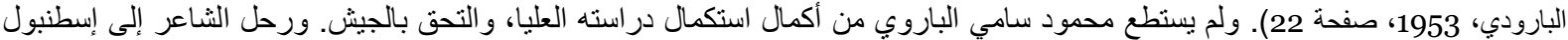
في عام 1857، وفي أثناء إقامته هناك تمكن من إتقان اللغة التركية و اللغة الفارسية ومطالعة آدابهما، وحفظ كثيرًا من أشعار هما. والثيا

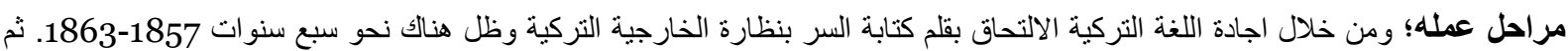

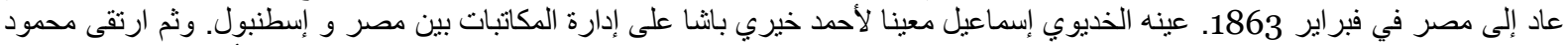

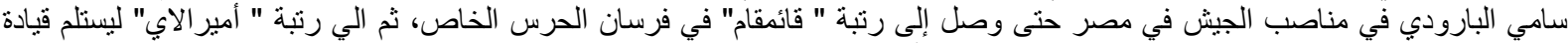

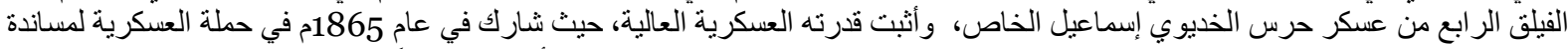

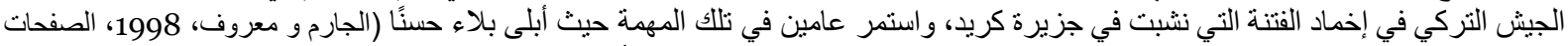

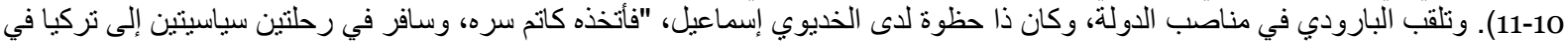

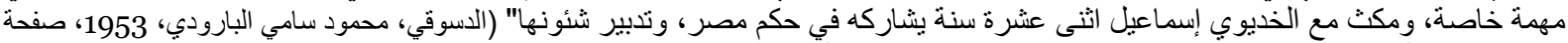

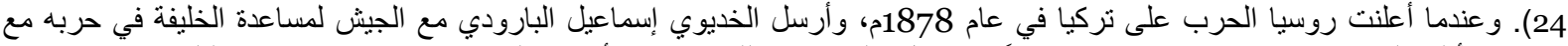

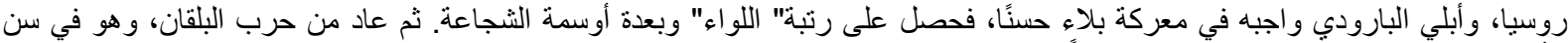

الأربعين، فعين مديرًا للثرقية ثم الصبح في محافظًا للعاصمة.

وفاته؛ تقلب البارودي في مناصب إدارية وسياسية كثيرة انتهت به إلى رئاسة النظار. واستقال البارودي ولما بدأت "الثورة العربية" كان هو في بإني

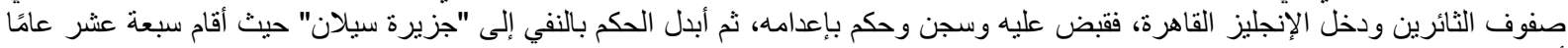

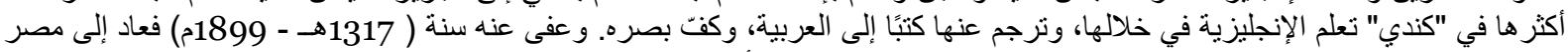

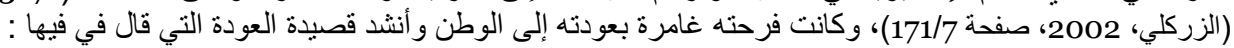

$$
\begin{aligned}
& \text { فإنّى أرى فيها عيـــوناً هى 'البِـحرُ }
\end{aligned}
$$

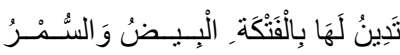

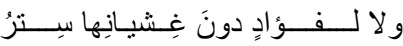

فـذلِلكَ عصرُ المعجِزاتِ، وذا عـصرُ (الجارم و معروف، 1998، صفحة

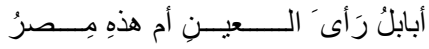

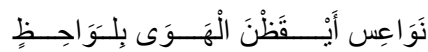

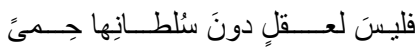

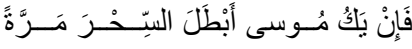

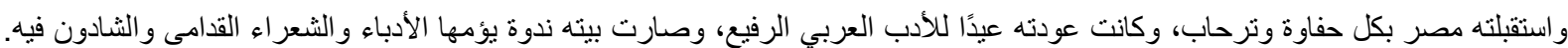

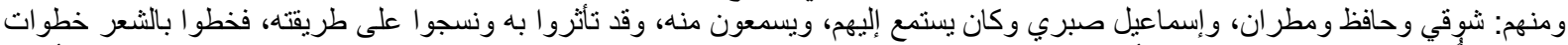

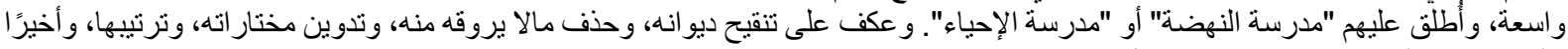

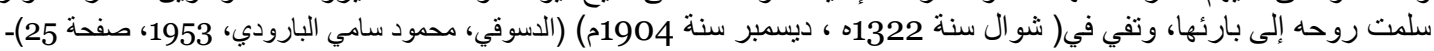

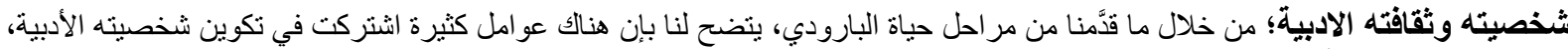

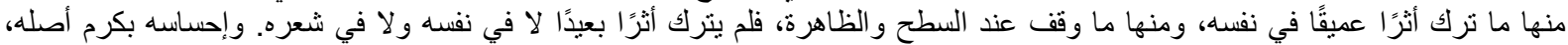

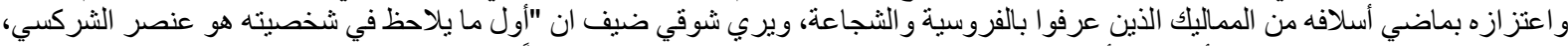

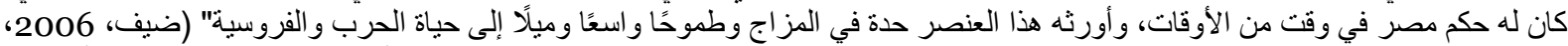

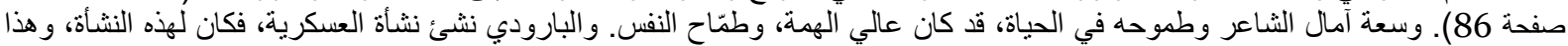

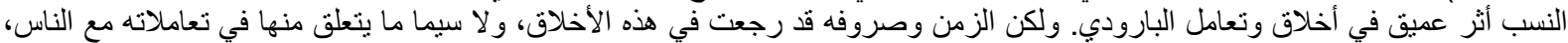

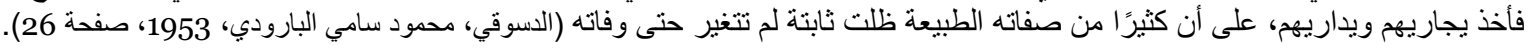

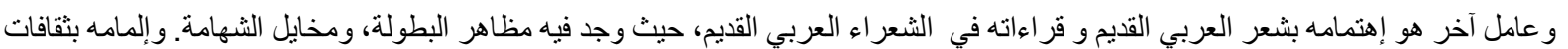

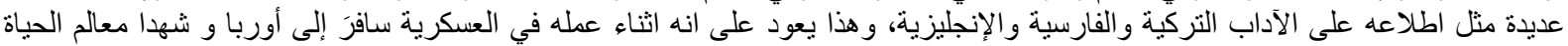

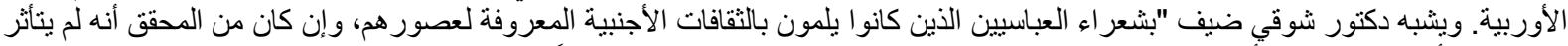

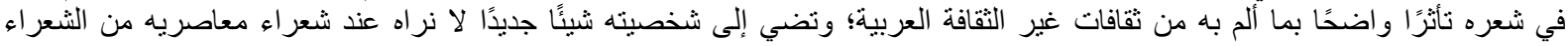

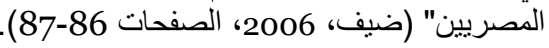

ومن عوامل آخرى كان له اثر كبير في تكوين شخصيته الادبية هو عنصر الحياة المصرية التي اضطرب في مشاهدها الطبيعة وأحداثها القومية

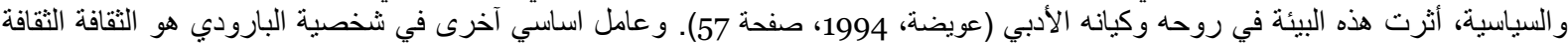

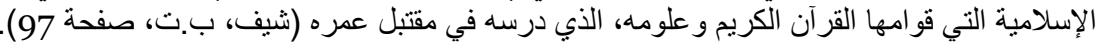

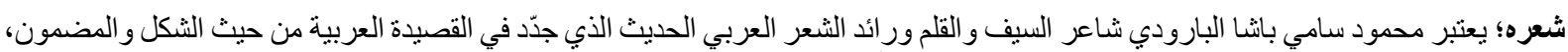

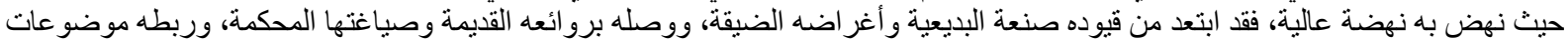

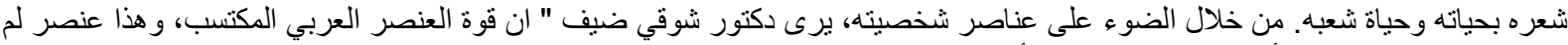

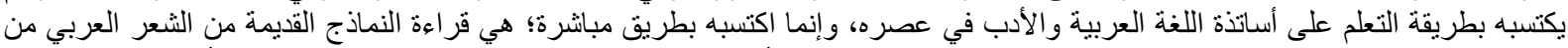

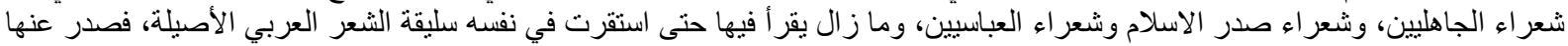

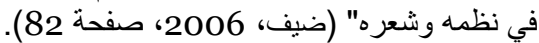

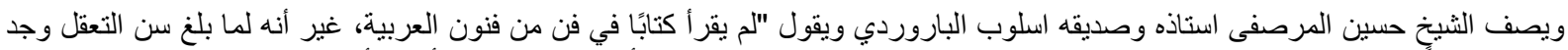

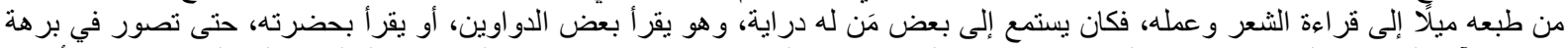

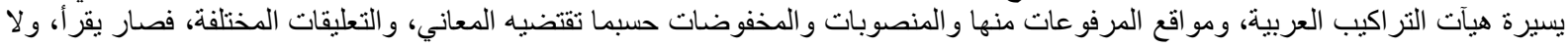


يكاد يلحن. ثم استقل بقر اءة دو اوين الثعر ومثاهير الثعر اء من العرب، حتى حفظ الكثير منها دون كلفة، واستثبت جميع معانيها ناقدًا شريفها من

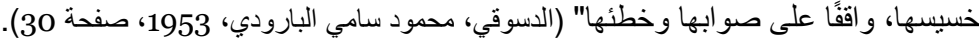

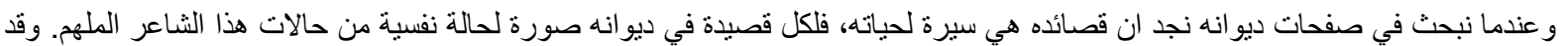

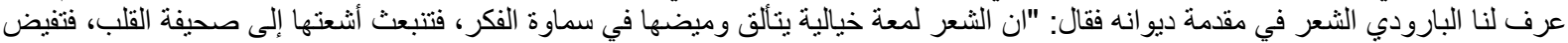

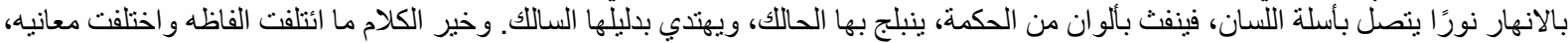

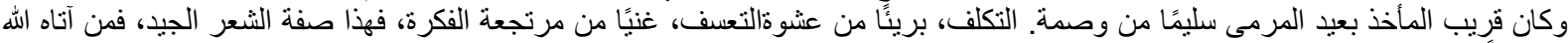

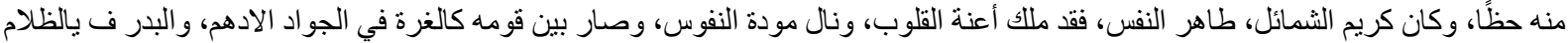

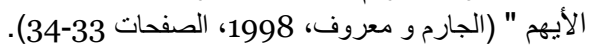

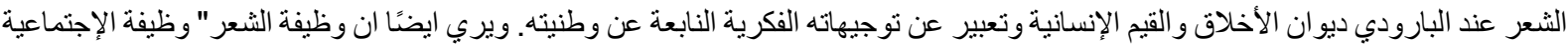

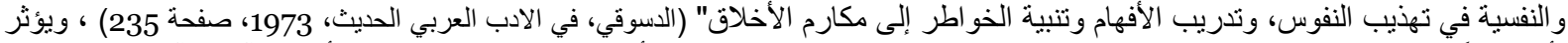

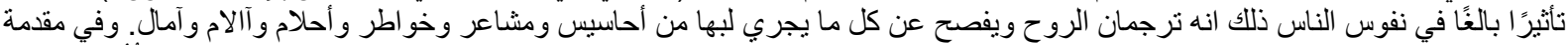

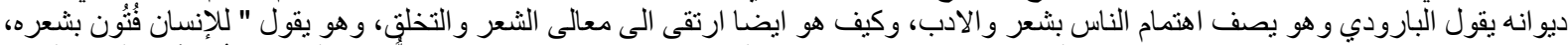

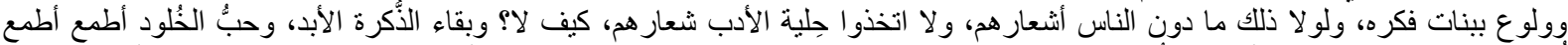

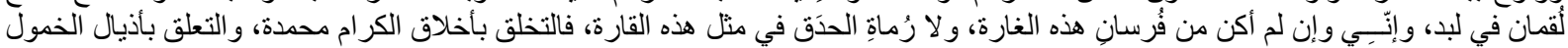

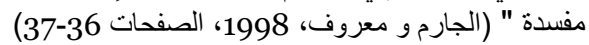

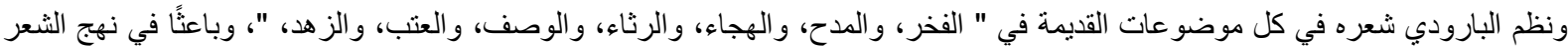

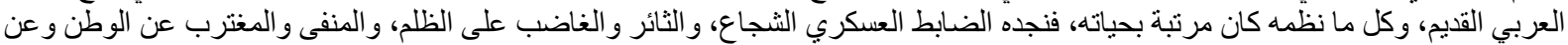

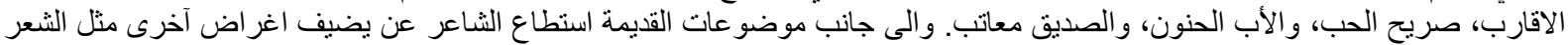

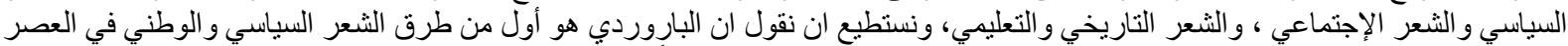

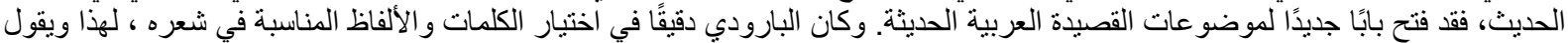

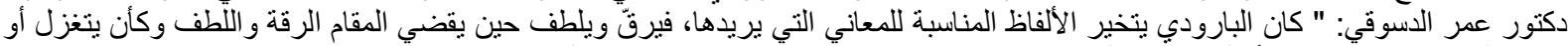

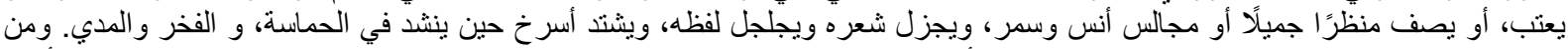

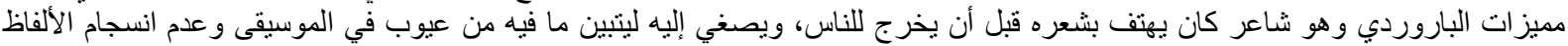

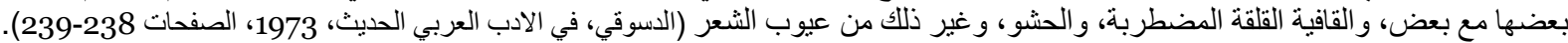
وينشد رأيه في الثعر في قصيدة "الثعر زين المرء" ويقة ويقول:

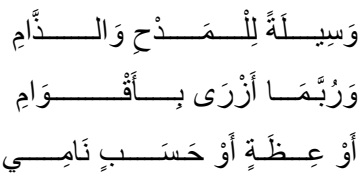

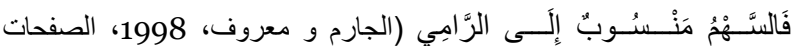

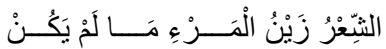

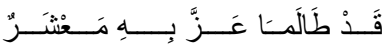

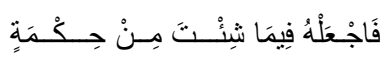

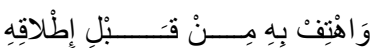

(600-599

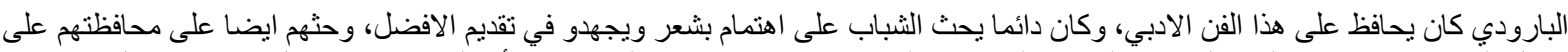

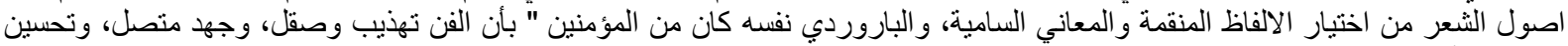

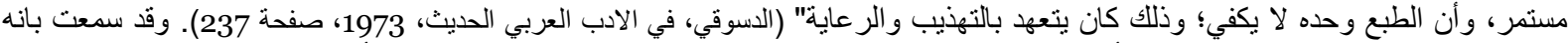

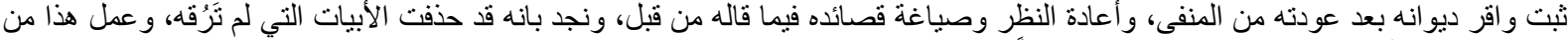

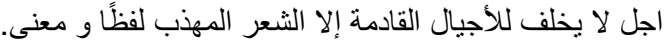

$$
\text { آثاره؛ للبارودي مجمو عة من مؤلفات منها: }
$$

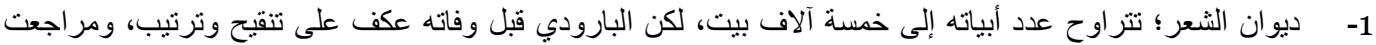

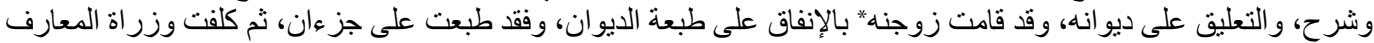

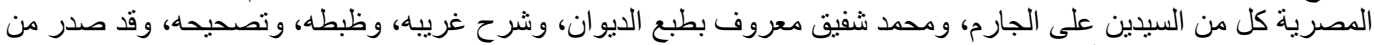

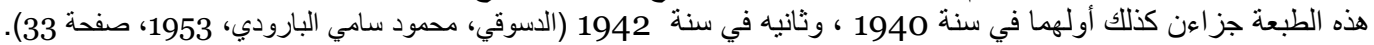

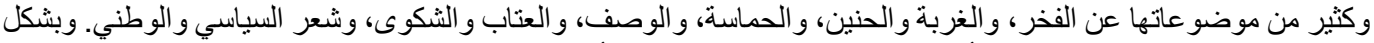

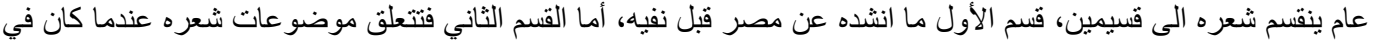

2- مختار ات البارودي؛ مجموع من مقتطفات الثعرية يبلغ نحو 40 ألف بيت لثناثثين شاعرًا من الثعر العباسي، ، وكما قال

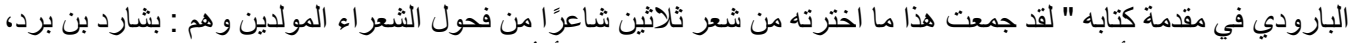

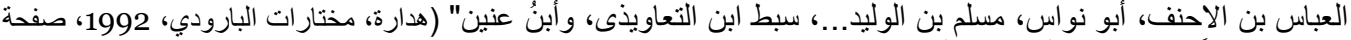

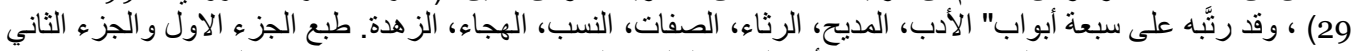

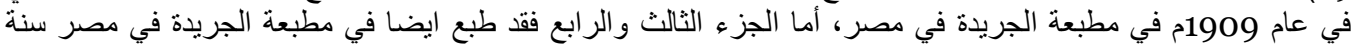

1911

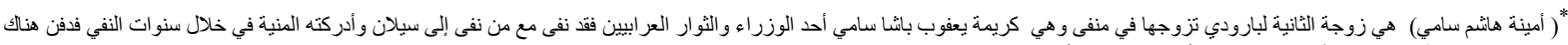

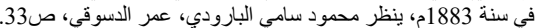

Kurklareli Üniversitesi, Fen Edebiyat Fakïltesi, Türk Bölümü, Kayalı Kampüsü-Kırklareli/TÜRKIYY e-posta: editor@rumelide.com
Adress

Kırklareli University, Faculty of Arts and Sciences, Department of Turkish Language and Literature, Kayalı Campus-Kirklareli/TURKEY e-mail: editor@rumelide.com 


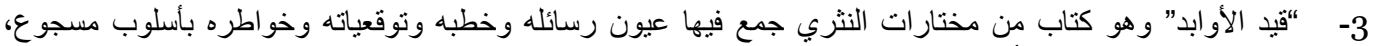

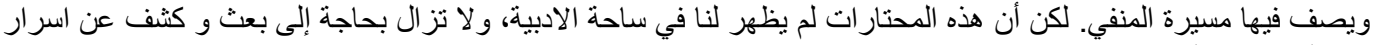
هذه المجمو عة الفنية.

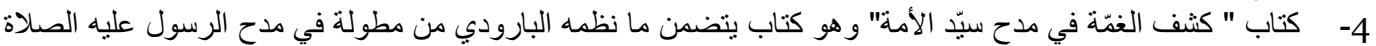

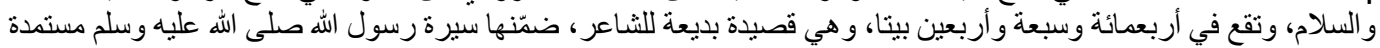

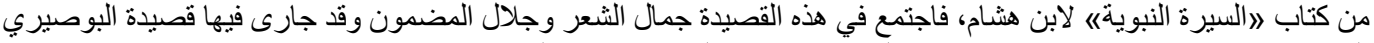

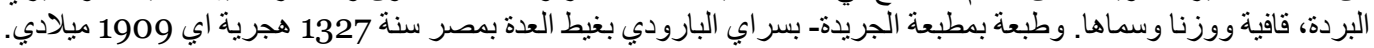

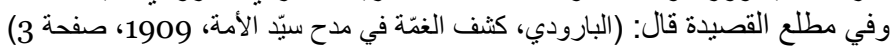

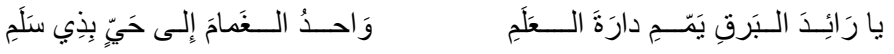

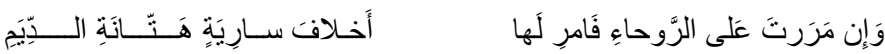

$$
\begin{aligned}
& \text { غرض العتاب عند البارودي }
\end{aligned}
$$

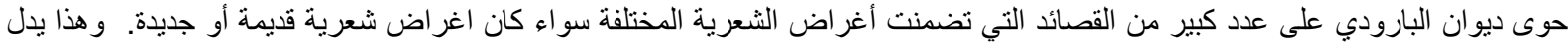

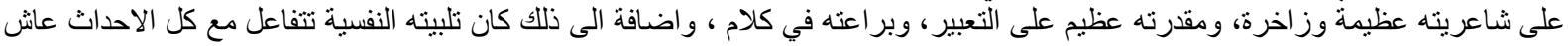

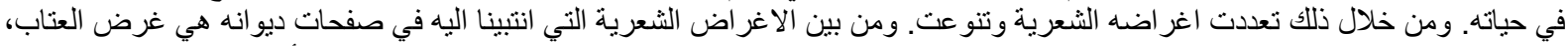

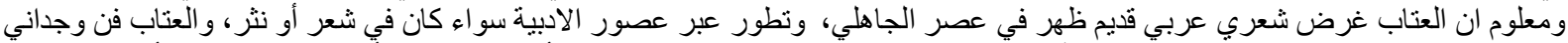

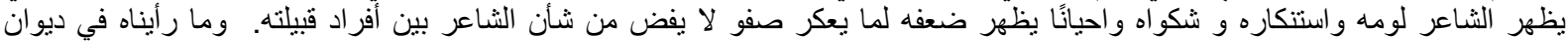

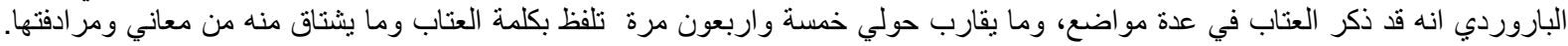

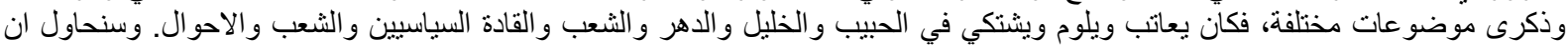

\section{العتاب الإجتماعي}

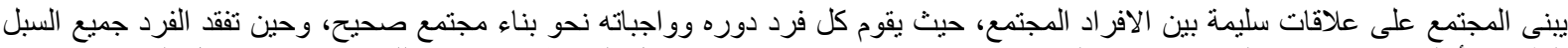

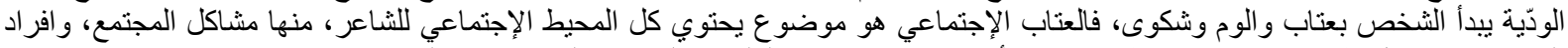

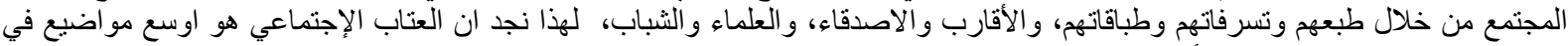

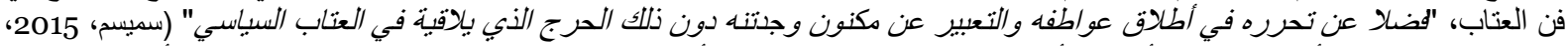

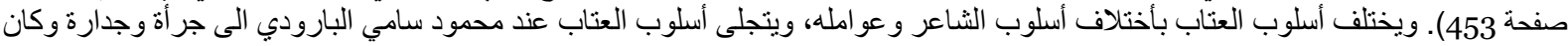

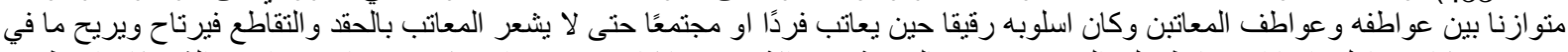

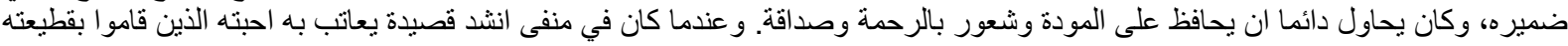

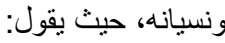

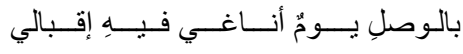

$$
\begin{aligned}
& \text { وَســاءَ صنـــعُع اللــــــالي بـعدَ إجــمالِ }
\end{aligned}
$$

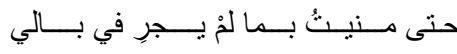

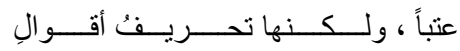

$$
\begin{aligned}
& \text { يـــا غاضبينَ علينا ! هلْ إلىى عـدةٍ }
\end{aligned}
$$

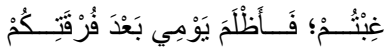

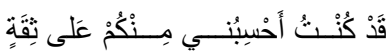

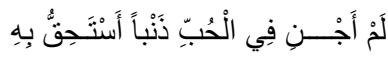

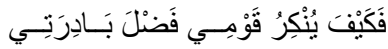

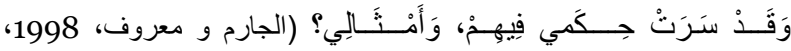

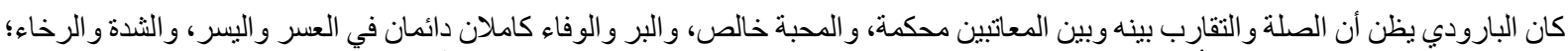

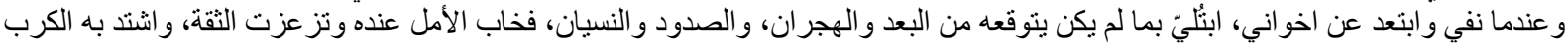

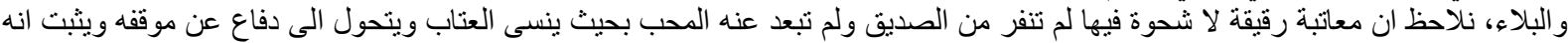

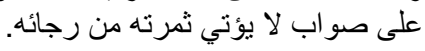

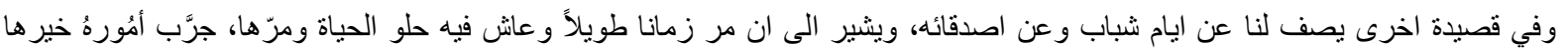

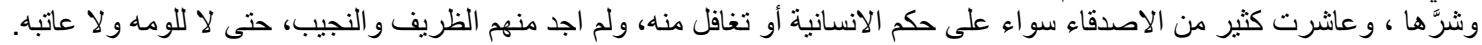

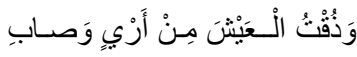

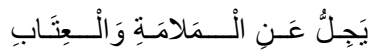

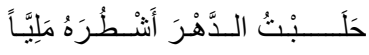

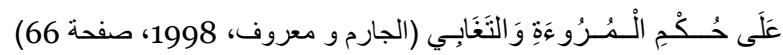

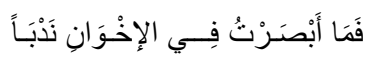

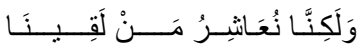




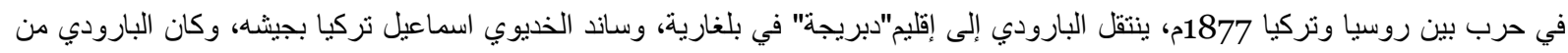

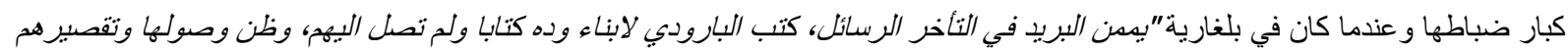

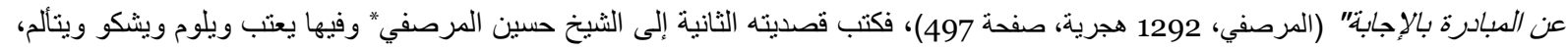
ويصف حاله على البعد وقد انقضت بشاثة العيش وساء المقام، ويتمنى أن يكون حرف من حروف التلغراف أو ريشة بين خو افى الحمام. ويبدأ بمطلع.

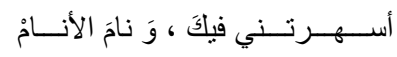

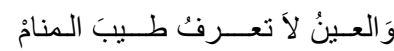

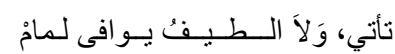

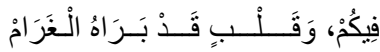

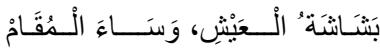

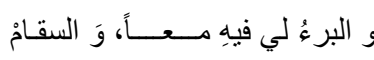

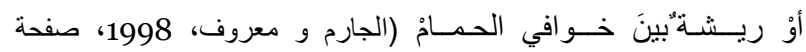

\section{بَعـدَ الو دادِ فَلَسبتُ مِنْ أَصْحَابِهِ}

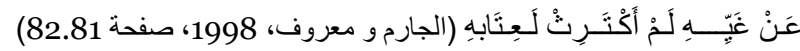

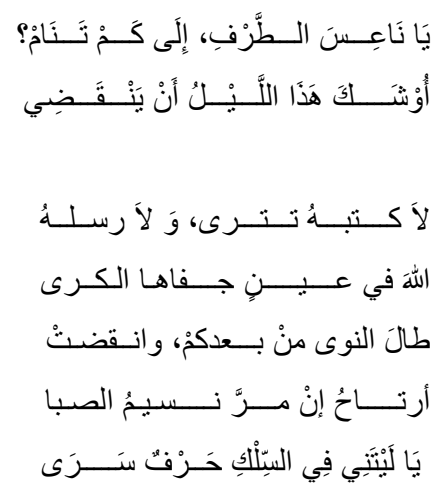

$(544.543$

ومن عتاب الاخو انياته يقول :

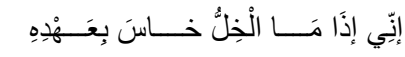

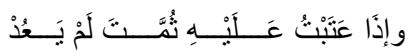
لم فيرجع عن ظلاله، لهذا اكثرت في في عتابه مرة اخئ اخرى.

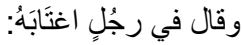

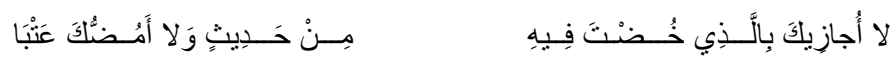

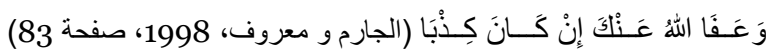

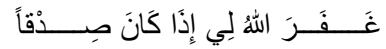

وفي قصيدة اخرى انثد قصيدة يعاتبُ صديقًا، و هو ايضا من عتاب الاخو انياته:

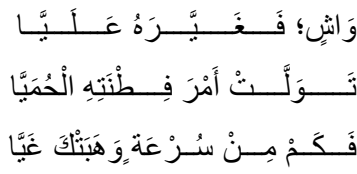

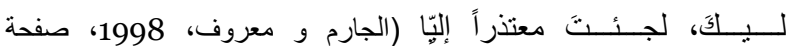

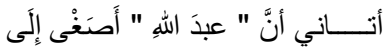

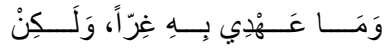

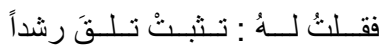

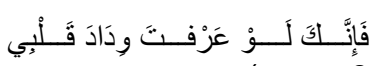

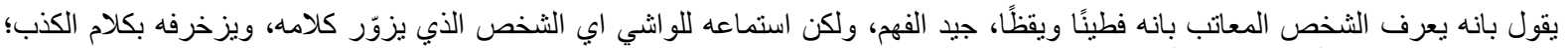

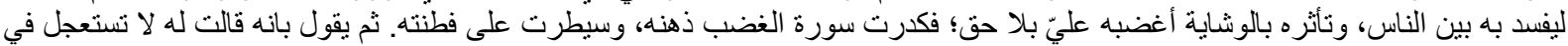

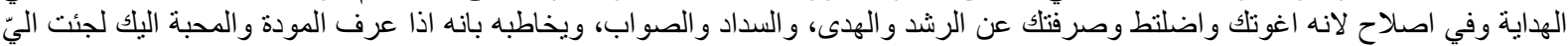
معتذر ا وانا كنت اقبل معذر لكأك.

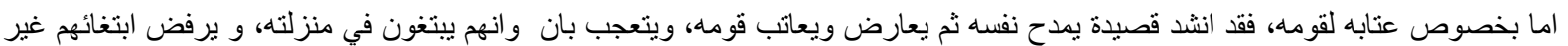

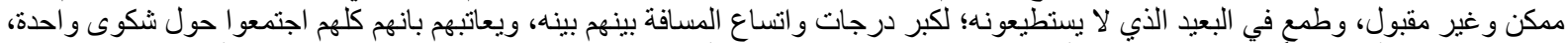

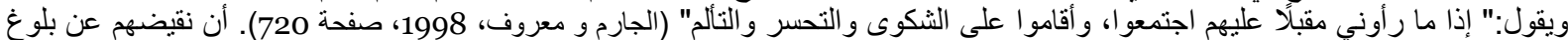

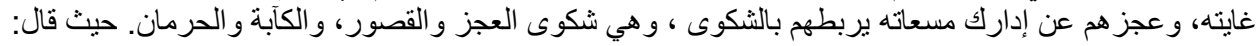

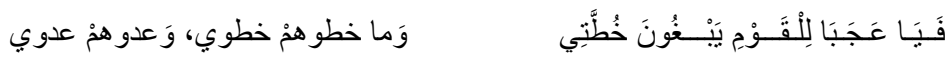

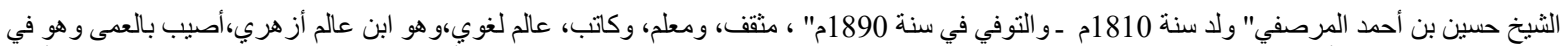

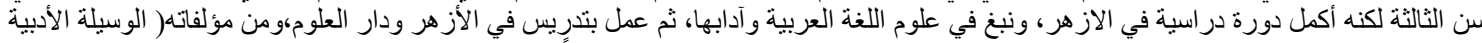

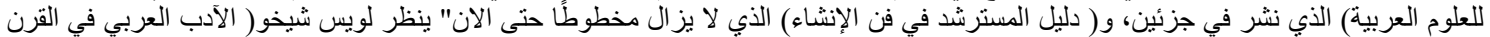

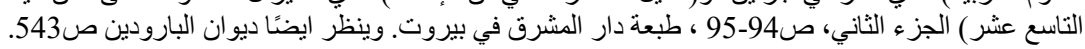




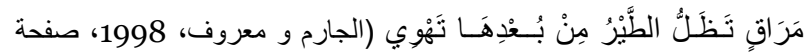

نجد يللوم ويعاتب بعض الاشخاص من مجتمعه على عدم التز امهم بمكارم و المعارف الاخلاق، ويعذر هم بان من كذب و سعى بين الناس بالفساد

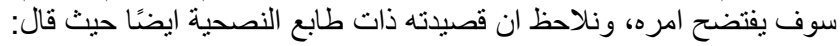

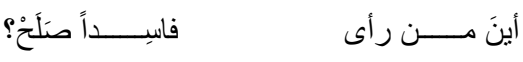

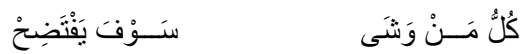

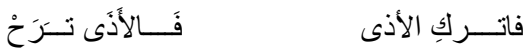

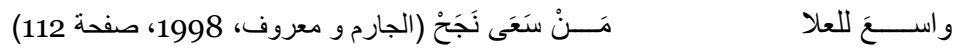

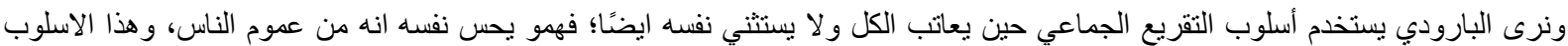

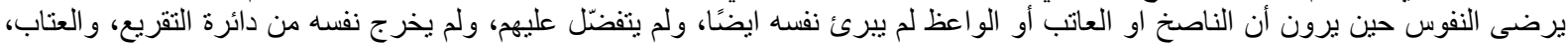

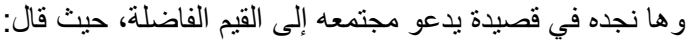

$$
\begin{aligned}
& \text { فَسِيََّانِ مَسنْ حَلَّ الْوِ هَادَ، وَمَنْ سَمَا }
\end{aligned}
$$

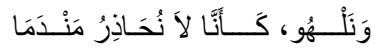

$$
\begin{aligned}
& \text { فإنْ نالها أنحى لأخرى، وصـمـما }
\end{aligned}
$$

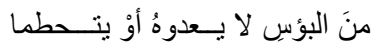$$
\text { إذا كـانَ عـــــــــى كـــلَّ حيَّ مــنية. }
$$

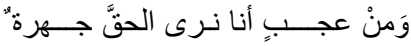

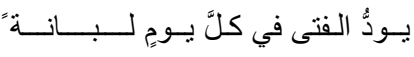

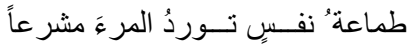

وَلَوْ رَامَ عِرْفَانَ الْحَقِيَةَة لانْتَهَى (الجارم و معروف، 1998، صفحة

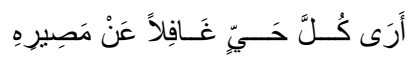

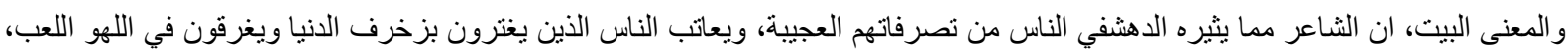

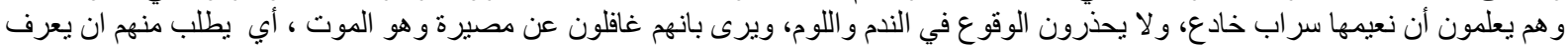

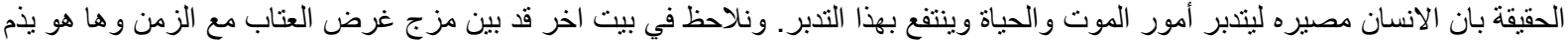

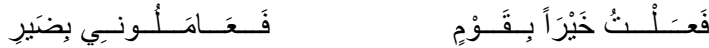

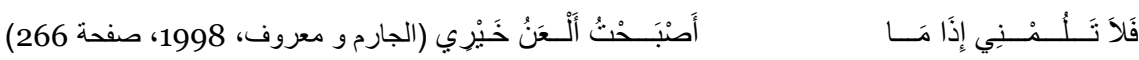

$$
\begin{aligned}
& \text { العتاب السياسي }
\end{aligned}
$$

ان السياسة هي مجمو عة من المبادئ و القو اعد التي أثتب التجريب صحتها والتي تتعلق بالسياسة، وهي ايضا لر عاية شئون الدولة سواء كان داخلية

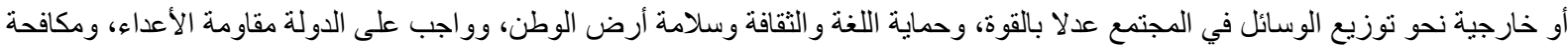

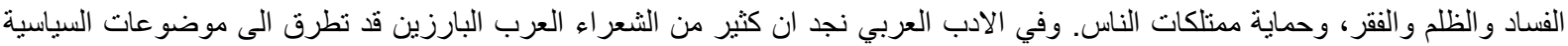
وكثير الاشعار هم مع ازدياد الاحداث السياسية في الوطن العربي. و وعاتب وشكا كثير من شعر اء من مشاكل السياسية و القانونية، ومن الأمير و الحاكم

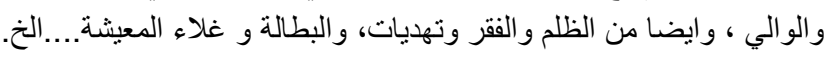

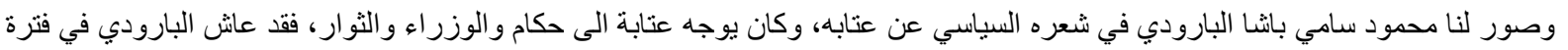

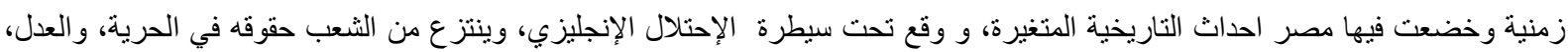

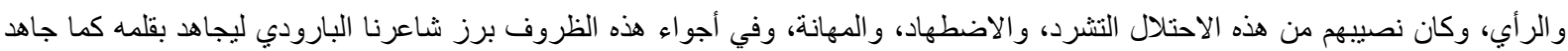

بسيفه.

وكان البارودي في شعره السياسي، بمثابة الناقد الاجتماعي، وثائر وطني، ومصلحا صريحًا حاد المشاعر . وكان شديد الإحساس على حرية ابناء

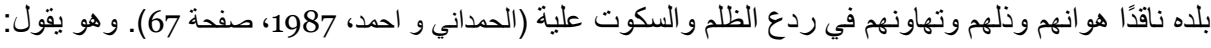

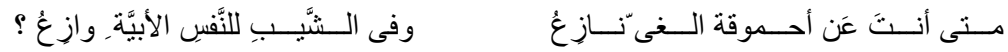

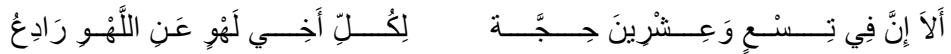

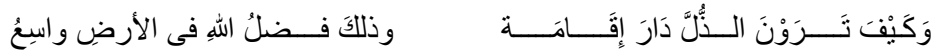

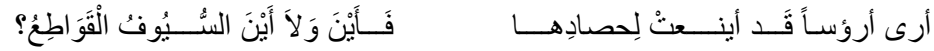




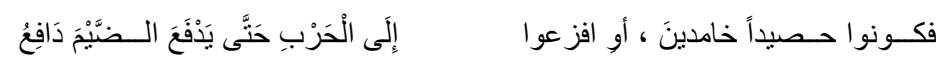

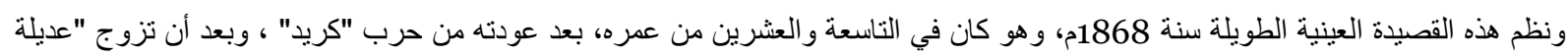

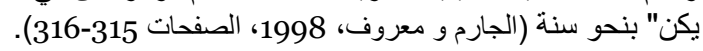

ونجد البارودي يعاتب على احدى الو لاة في يوم قطع سد النيل حيث يقول: (الجارم و معروف، 1998، صفحة 250)

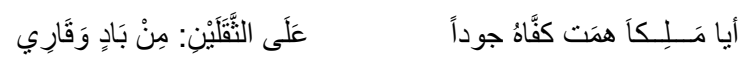

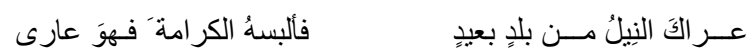

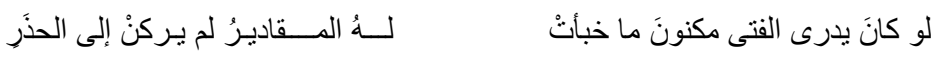

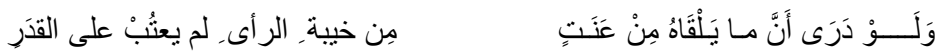

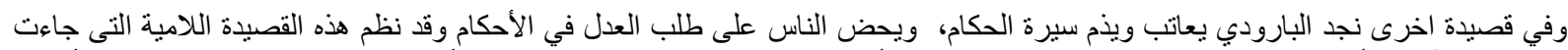

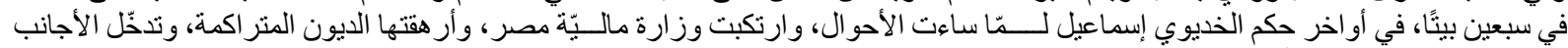

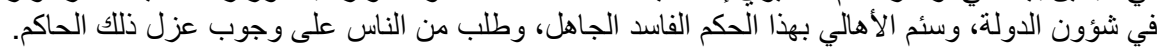

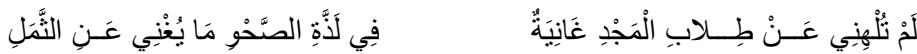

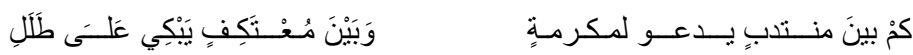

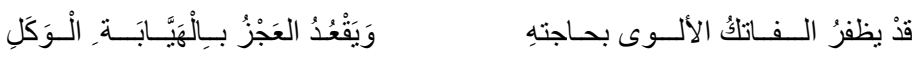

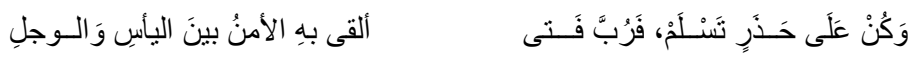

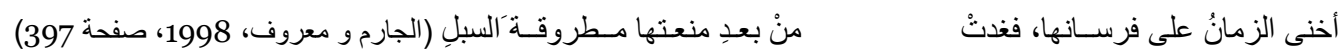

يقول كأن التـهّي سكر يحذر العقل ويخمره، و السعي في طلب المجد صحوة ينبهه ويذكيه، وأن الفرق شاسع، بين الداعي إلى المكرمات، و الباكي

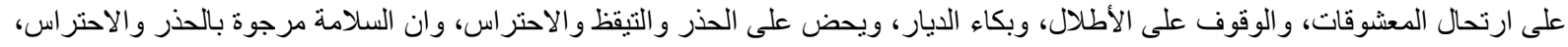
لا بالغفل و الاندفاع.

وفي قصيدة طويلة اخرى يعرض فيها البارودي الجند الذين تخاذلوا في الثورة العربية، ويشير الى اسباب الهزيمة هي عذم سماع الضباط الثورة

$$
\text { للنصيحته، ويعاتبهم ويقول : }
$$

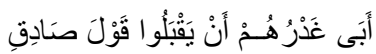

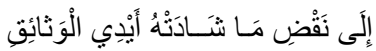

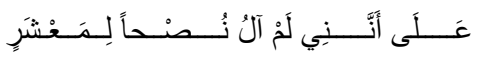

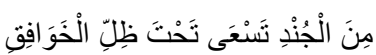

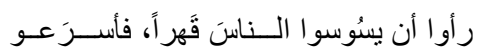

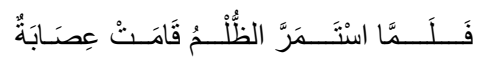

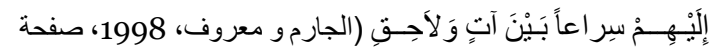

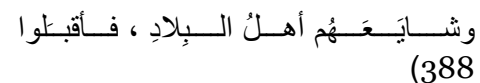

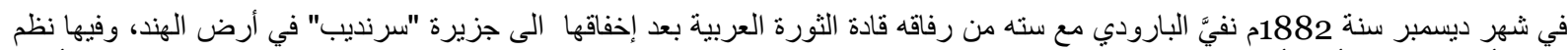

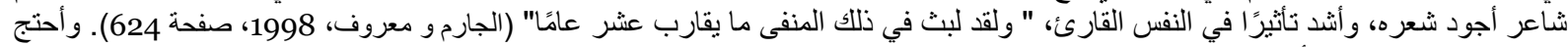

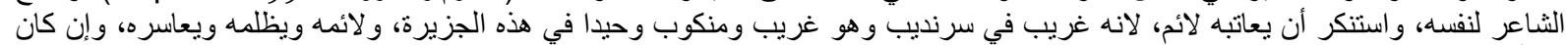

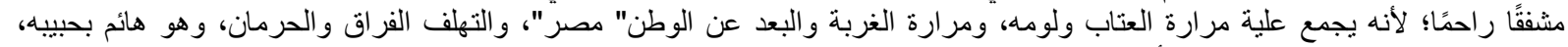

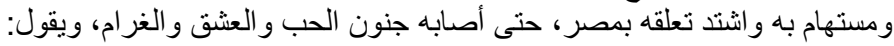

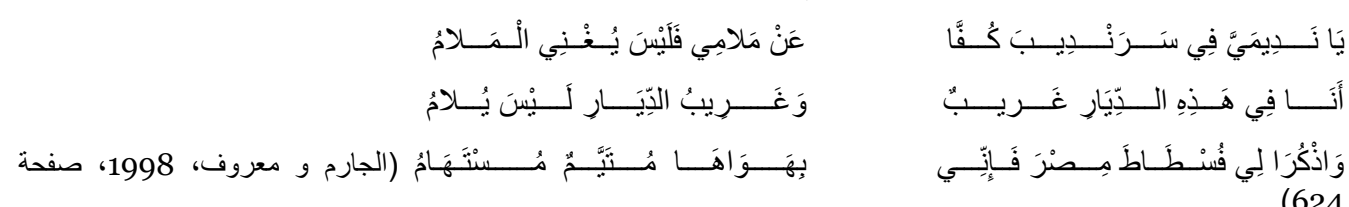




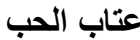

الباروردي أكثر في أيام شبابه من شعر الحب و الغزل، ولا عجب من ذلك فقد كان البارودي شاعرًا و فارسًا وذا مال وجاه، وهو من أبناء الطبقة

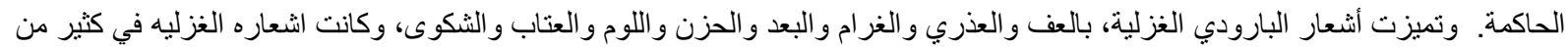

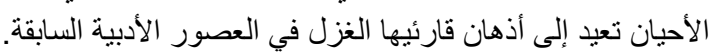

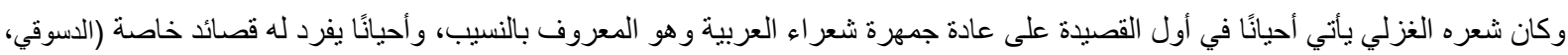

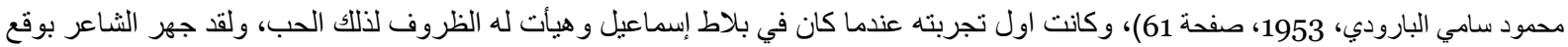

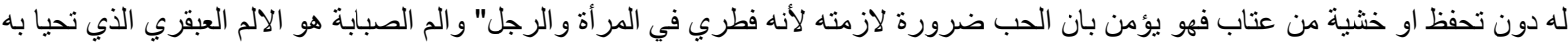

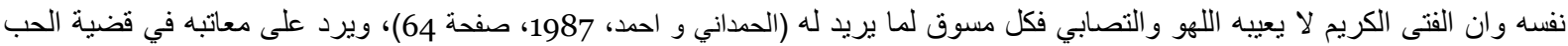

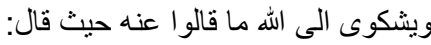

\section{حِمَى الْعَيْنِ حَنَّى أَوْرَدَنْبِي الْمَهَاوِيَـا

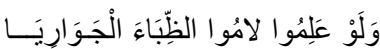

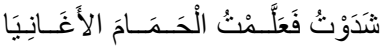

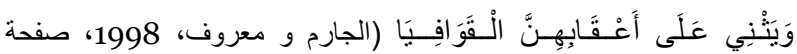

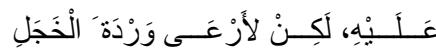

$$
\begin{aligned}
& \text { وررداً جـنـياً، جـــــاهُ رائـــُ الــــــــلِ (الجارم و معروف، 1998، صفحة }
\end{aligned}
$$

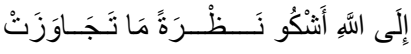

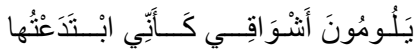

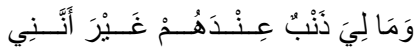

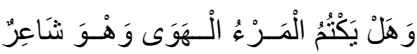

(726.724

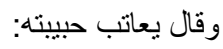

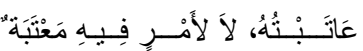

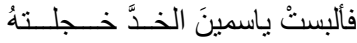

(495

في هذا البيت يوضح لن سبب العتاب لحبييته، لم يكن من حبيبه المتغزل به شيء يستحق العتاب؛ لكن عاتبه من اجل يخجله، فيستمع بالنظر إلى في إنى جمال حمرة الخجل في خديها التي تشبه زهرة الياسمين؛ ويتلمس في عيو نها و الباحث عنه، ويقطف لئه منهما وردتين كانتا نتيجة عتابه.

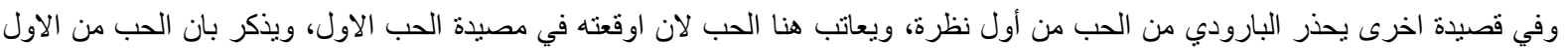

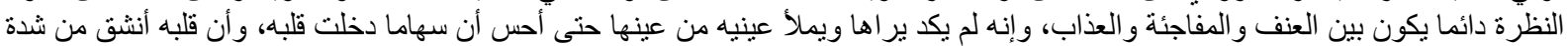

اشتياق لها، وذهب عنه الكبر والإعجاب بالنفس، ووقعت في مصيدة جمالها من خلال شعر ها على على أثفار عينها.

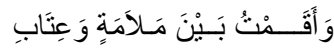

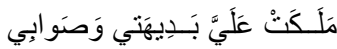

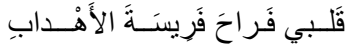

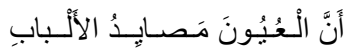

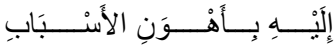

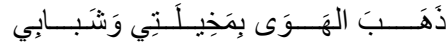

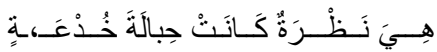

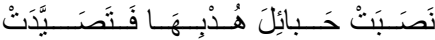

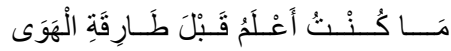$$
\text { وَمنَ الْعَجائبِب في الْهَوَى أَنَّ الفَتَى بُدْعَى }
$$

راضِ بِسُقْمِي فِي الْهَوَى وَعَذَابِي (الجارم و معروف، 1998، صفحة 80.79)

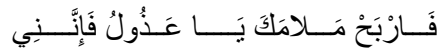

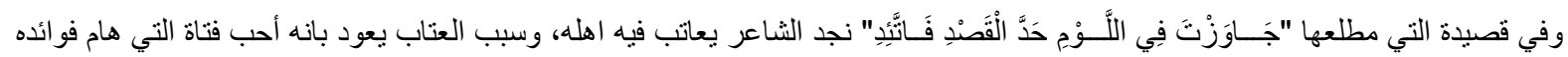

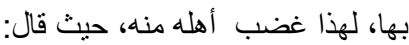

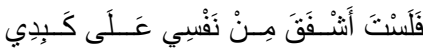

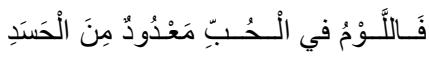

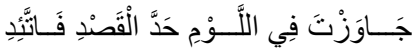

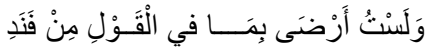

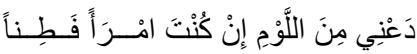

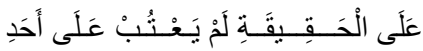

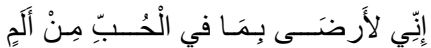

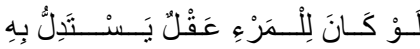

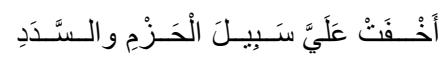

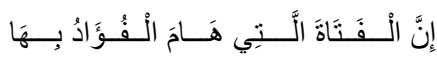




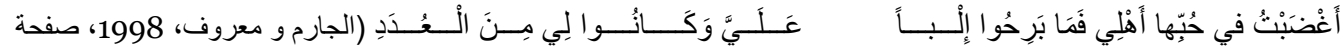

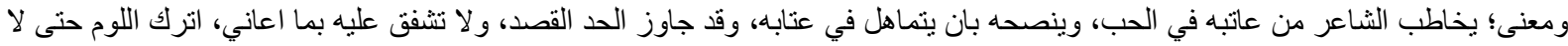

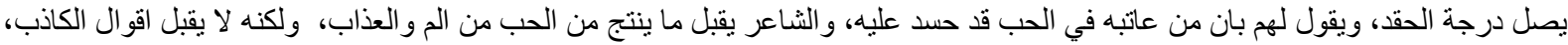

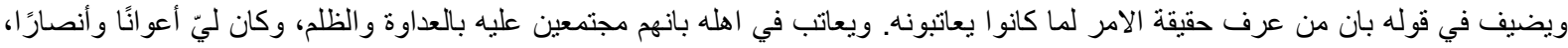

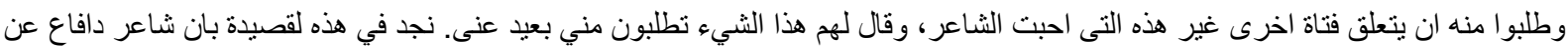

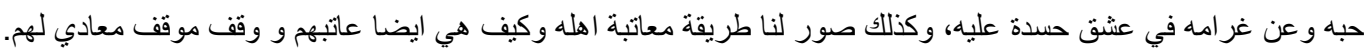

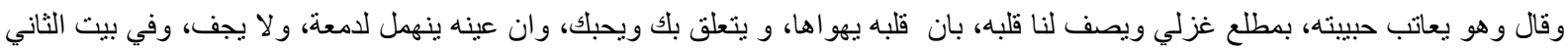

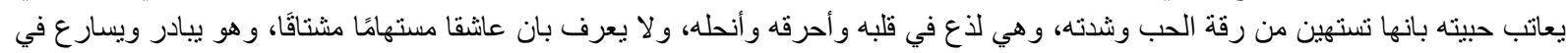
لقائها.

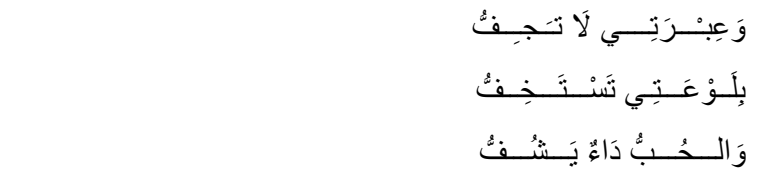

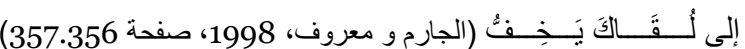

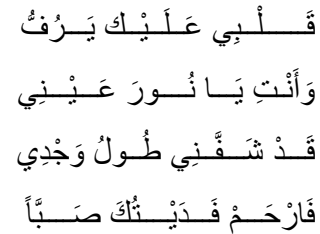

عتاب الدّهر

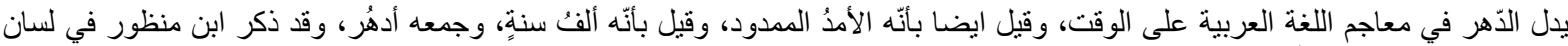

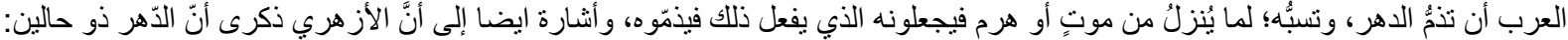

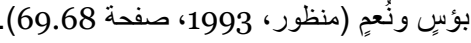

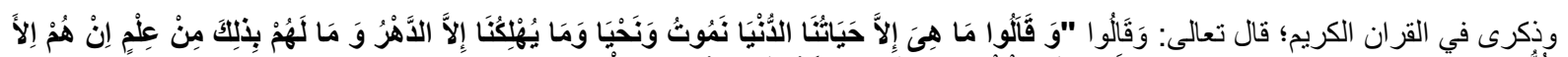

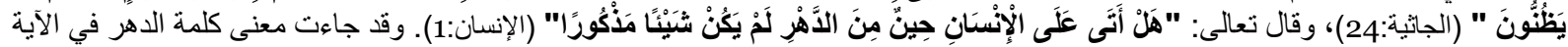

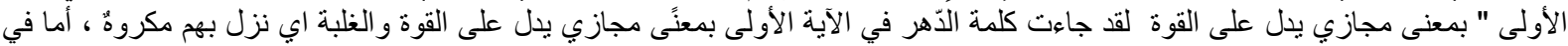

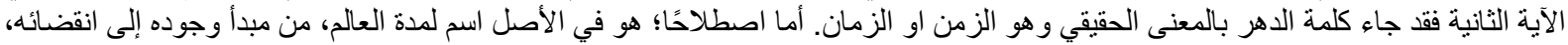

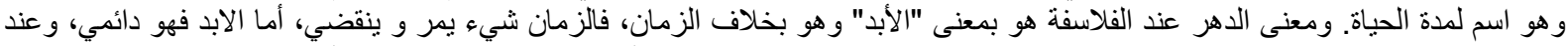

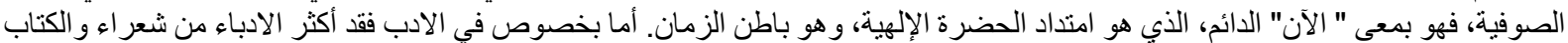

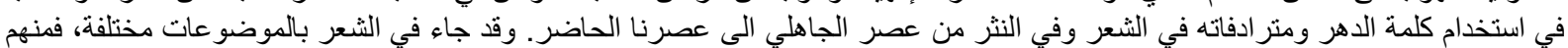

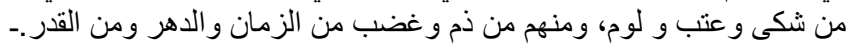

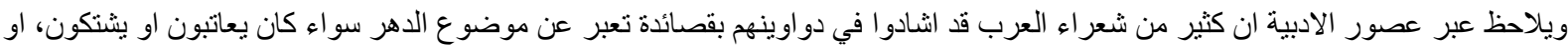

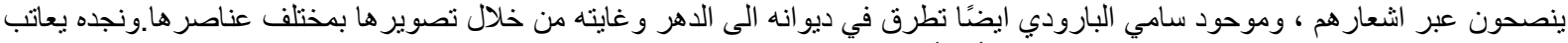

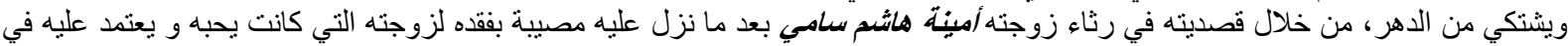

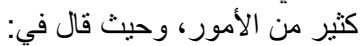

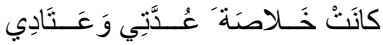

$$
\begin{aligned}
& \text { أفلا رحِمتَ مــنَ الأســـى أولادي؟ } \\
& \text { قــرحَّى الـعيـونِ رواجِفَ الأكباد }
\end{aligned}
$$

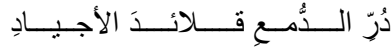

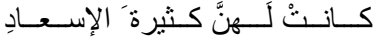

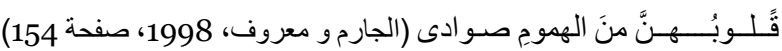

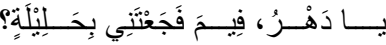

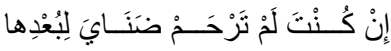

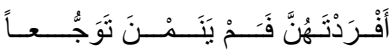

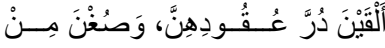

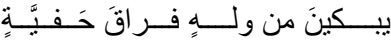

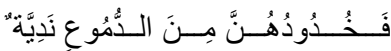

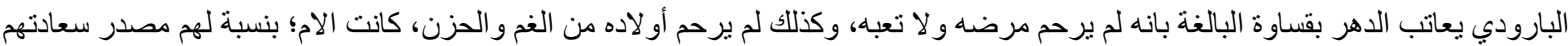

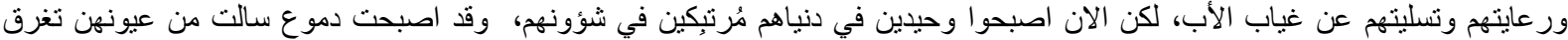
أعناقهن، يبكين على فراق الكريمة التي بالغت و أفرطت في إسعادهن ، و صارت خدودهن مبنلت من الدموع، و اصبحت قلوبهن فئن محترقة بسبب الهموم والأحزان.

وفي قصيدة اخرى نرى البارودي يعاتب الدهر ما حال إلبه، ويطلب منه ان يعيد إليه أيام شبابه، ويقول: 


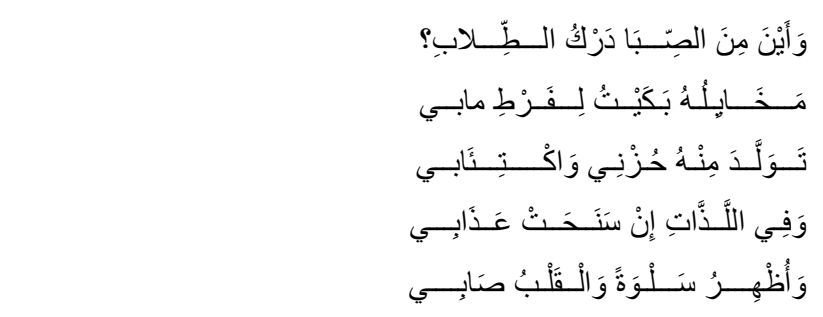

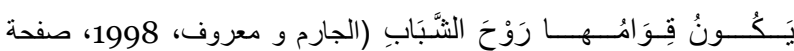

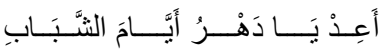

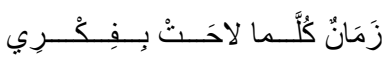

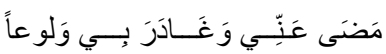

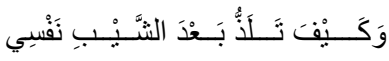

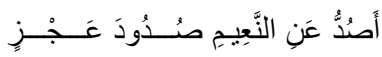

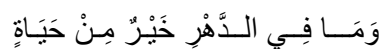

هنا الثاعر يطلب ويتمنى من الدهر ان يعيد إليه من ذكرياته وصوره، ويعاتب الدهر بانهانه هو المسبب في بكائه وفي شيخوخته، وانه دائما يفكر بالايام شبابه وهو مولع به، وقلبه الان جاهل عما يرى، وما في في الزمان ومان غير ايام الثباب.

وقال ايضا عن ايام شبابه :

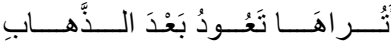

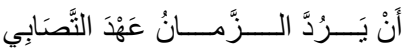

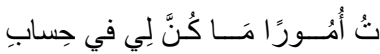

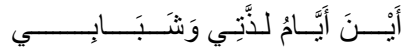

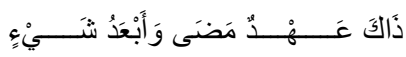

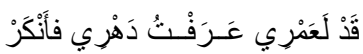

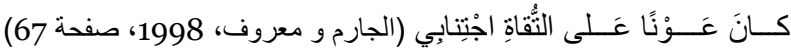

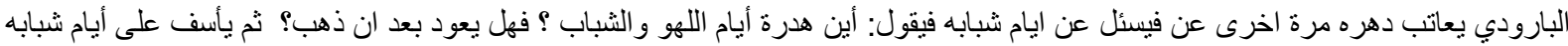

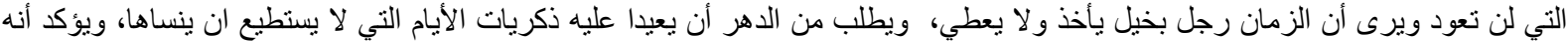

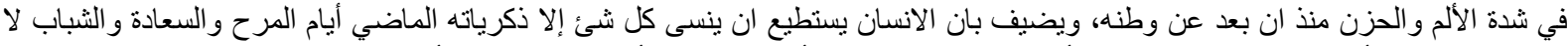

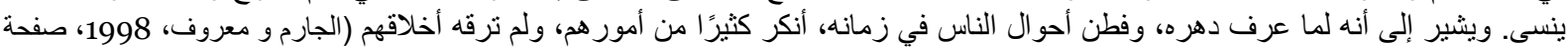

ويرى البارودي ان الابتعاد عن كثرة اللوم والعتاب الدهر، يعود إلى العقل لأنَّ هو الذي يريد الإنسان عن خفة العقل، والجهل وحسن التصرف.

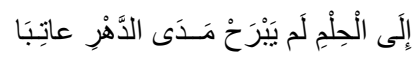

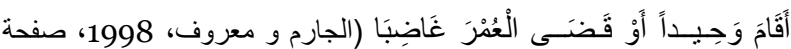

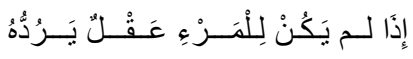

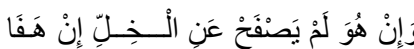

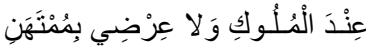

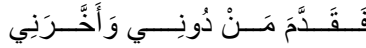

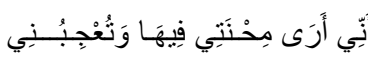

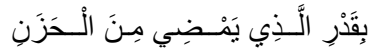

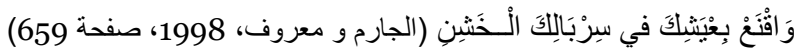

$$
\text { البارودي قال في صباه وهو يعاتب على دهره ، حيث قال: }
$$

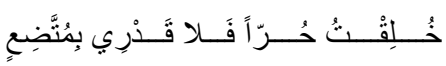$$
\text { لا عَنْبَ فِيَّ سبوَى أَنْيَ عَتَنْتُ عَلَى دَهْرِي }
$$

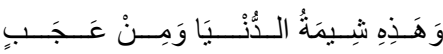

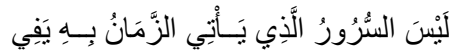

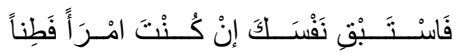

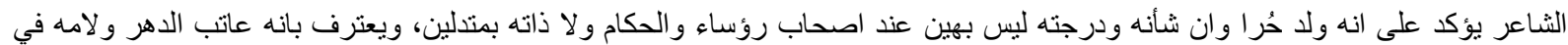

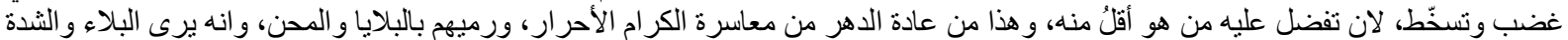

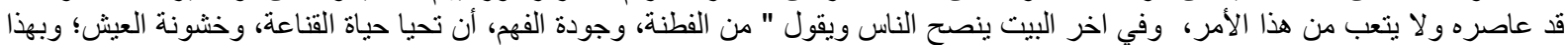

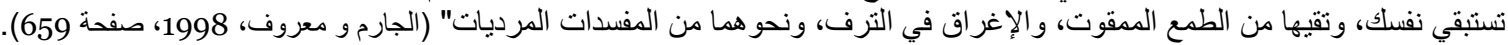
، العتاب و الثنكوى كثيرًا ما نعثر بين صفحات اشعارها من زفرات الألم المحموم مخلوطة بعبير الفخر الثابت أمام قضايا الدهر من نو ائبِه وشَدَائدِه

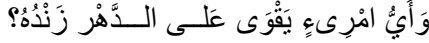

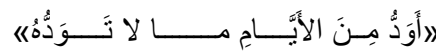

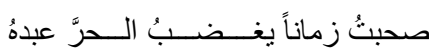

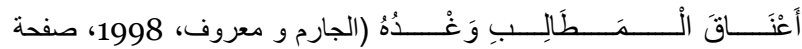

$$
\begin{aligned}
& \text { رضـــــنُ مـنَ الــنــيا بــما لا أودُهُ }
\end{aligned}
$$

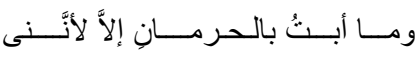

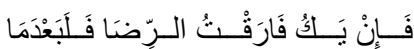

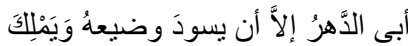




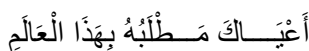

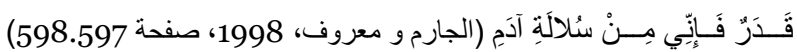

الثاعر هنا في هذا البيت يشير الى ذنبه في معاتبه كان من شؤون التي جرى بها قدر الله تعالي فلا ينبغي أن ينكر عليه ويؤاخذه به.

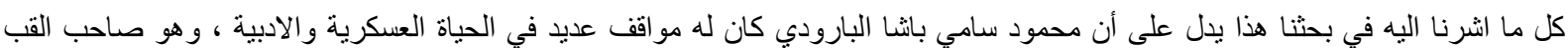

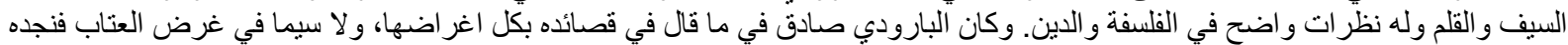

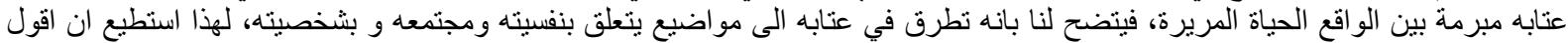

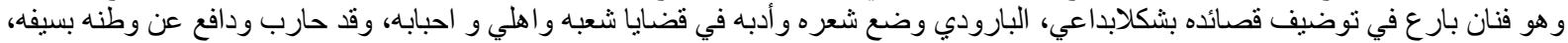

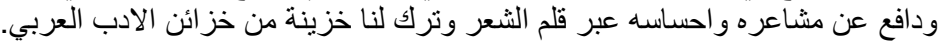

النتائج
\end{abstract}

من خلال ما قدمناه في بحثنا هذا توصلنا الى بعض النتائج منها:

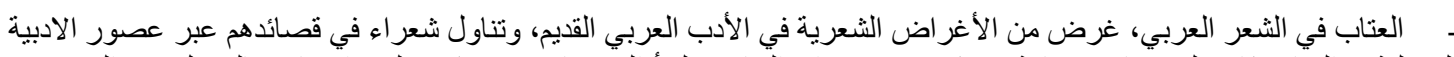

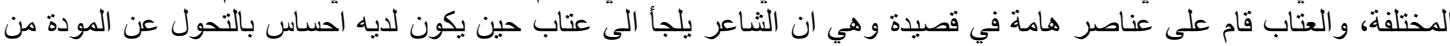

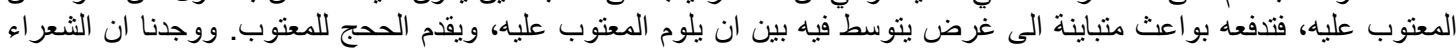

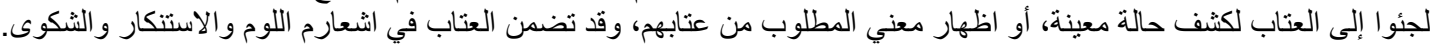

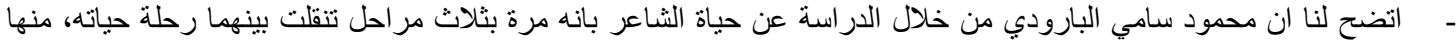

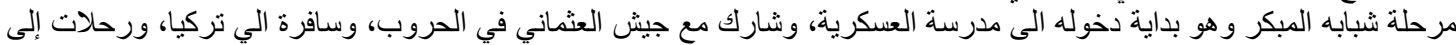

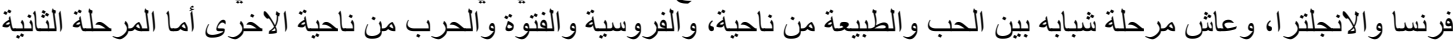

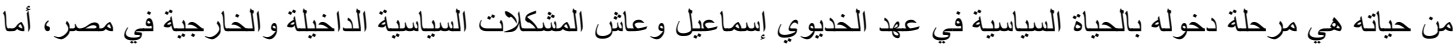

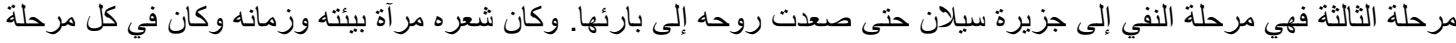

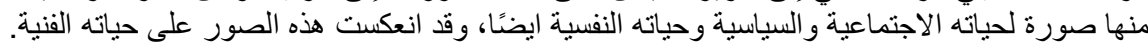

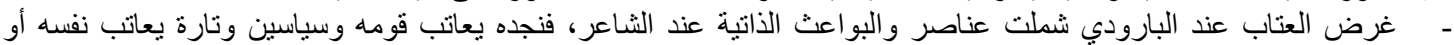

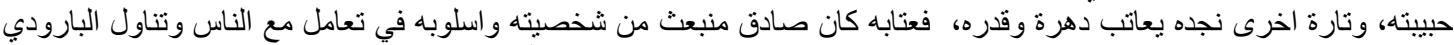

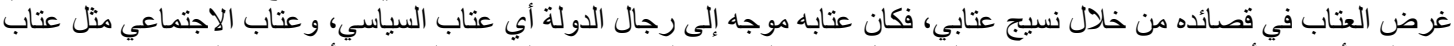

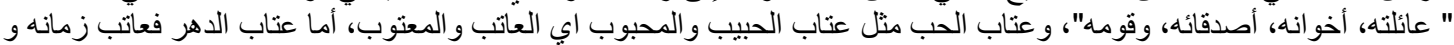

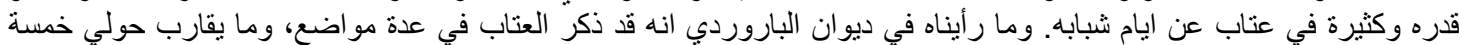

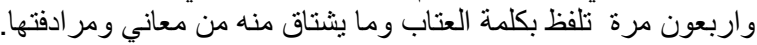

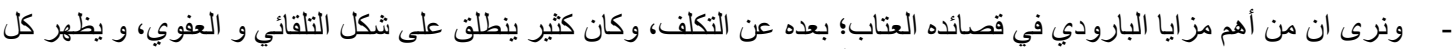

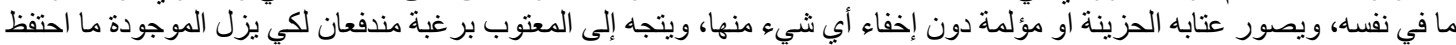

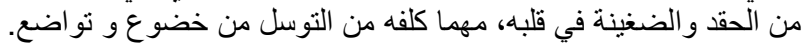

$$
\begin{aligned}
& \text { كتابيات } \\
& \text { الاز هري ,م .ب .(2001) بتهذيب اللغة .بيروت :دار إحياء التراث العربي . } \\
& \text { الإنسان.) (tarih yok) } \\
& \text { البارودي ,م .س .(1909) كثثف الغَّة في مدح سبّد الأمة .مصر :مطبعة الجريدة. } \\
& \text { البارودي ,م .س .(1909) كثثف الغدّة في مدح سبّب الأمة .مصر :مطبعة الجريدة. } \\
& \text { البارودي ,م .س .(1971) بديوان البارودي .القاهرة :دار المعارف. } \\
& \text { البصري , . .ب .1971) .لفرج بعد الثدة .بيروت :دار الكتب العلمية. }
\end{aligned}
$$

الجاثية.24. (tarih yok) 
الجارم ,ت . ع \& . معروف , . 1998) بديوان محمود سامي باشا البارودي .بيروت :مطبعة دار العودة. الجبوري ,م .(1974) أبام العرب في الجاهلية قيمتها التاريخية أثثرها منذ الجاهليين والاسلامبين .بغداد :منثورات وزراة الإعلام . الجهم ,ع عب) .ب.ط ـ.ديوان علي بن الجهم .جدة :وزراة المعارف السعودية.

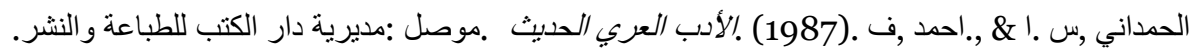
الدسوقي ,ع (1953) محمود سامي البارودي .القاهرة :دار المعارف. الدسوقي ,ع .(1973) في الادب العربي الحديث .القاهرة :دار الفكر. الرازي ,ع .ب . (1983) مختار الصحاح .كويت :دار الرسالة. الزركلي ,خ .(2002) .الأعلام، قاموس تراجم لأشهر الرجال والنساء من العرب والدستعربين والمستشرقين .بيروت :دار العلم للملايين.

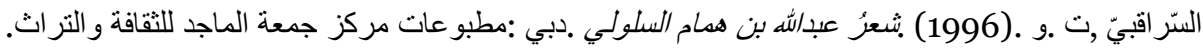
الثايب , أ . (1976) بتاريخ الشعر السياسي إلى منتصف القرن الثاني الهجري .القاهرة :مكتبة النهضة المصرية. العسكري , أ هـ (1994) .بيوان الدعاني .بيروت :دار الكتب العالمية. القرطبي ,ب .ع) .ب،ط .(بهجة الدجالس، وأنس الدجالس وشحذ الذاهن والهاجن .بيروت :دار الكتب العلمية . الكريم , . (1996) .القران الكريم .المدينة المنورة :مجمع الملك فهد لطباعة المصحف الثريف. المدني ,ع .ص .(1968) أنواع الربيع في أنواع البديع .النجف :مطبعة النعمان . المرصفي ,ح 1292) ـهجرية .(الوسبلة الادبية للعلوم العربية. .القاهرة :طبعت بمطبعة الددارس الملكية بدرب الجماهير. تحقيق عباس عبد الساتر. (1996). ديوان النابغة الذبياني. بيروت: دار الكتب العلمية. جابر رر .م .2013) .العتاب في الشعر العباسي مجلة كلية التربية الأساسية .509-517, سميسم ,و .ك .2015) .فن العتاب في الثعر الأموي .مجلة اللغة العربية وادابها 468-438 , شيف رش) .ب.ط .(لبارودي رائد الشعر الحديث .القاهرة :دار المعارف. ضيف ,س .(2006).ألادب العربي المعاصر في مصر .القاهرة :دار المعارف. طوقان ,إ .2012) ـالأعمال الشعرية الكاملة لابر/هيم طوقان .نصر :مؤسسة هنداوي للتعليم والثقافة. . على فاعور. (1997). ديوان كعب بن زهير. بيروت: دار الكتب العلية.

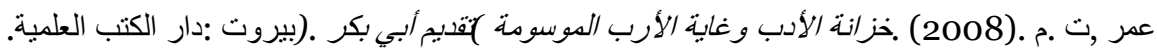

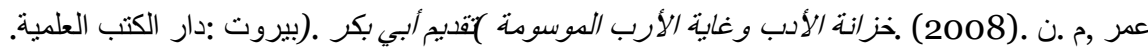
عويضة ,ك .م .(1994) محمود سامي البارودي إمام الشعراء في العصر الحديث .بيروت :دار الكتب العلمية. 


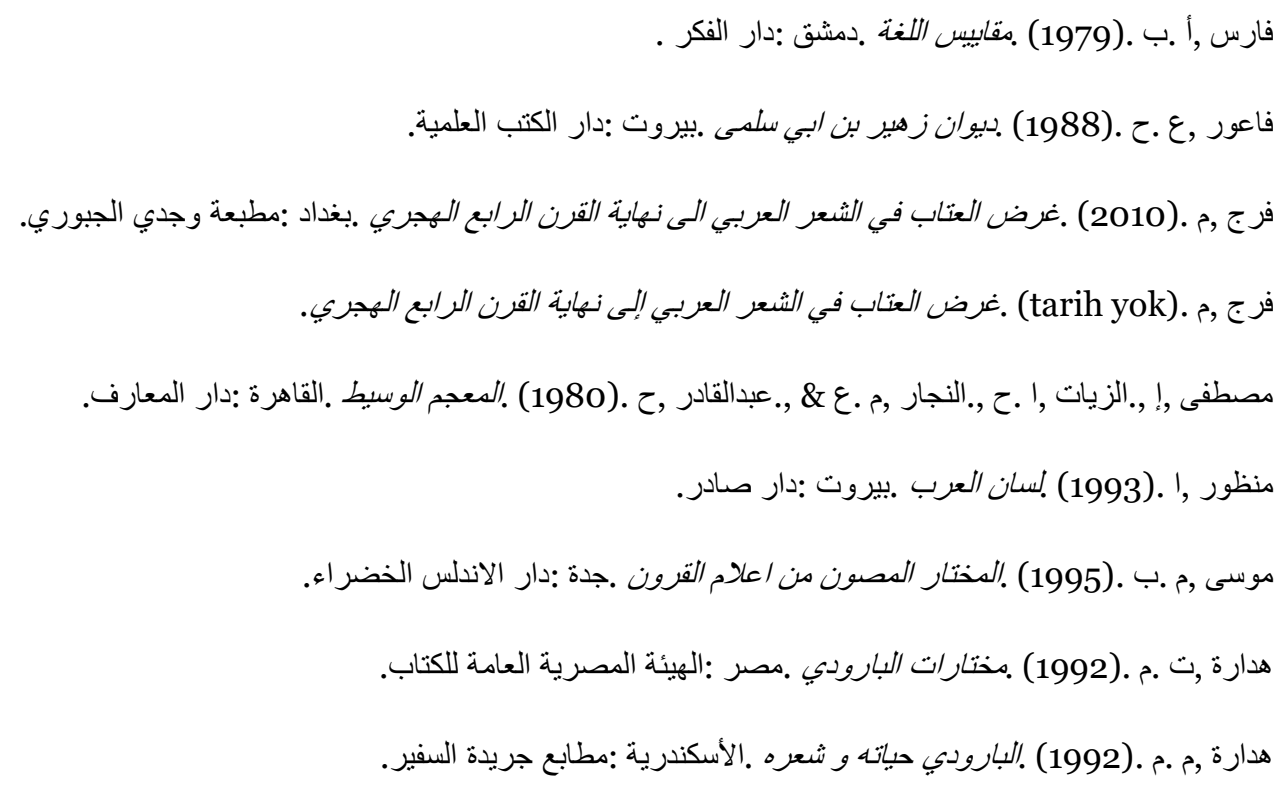

